Delivering value in projects and project-based business

Special issue for International Journal of Project Management

\title{
CO-CREATION OF VALUE OUTCOMES: A CLIENT PERSPECTIVE ON SERVICE PROVISION IN PROJECTS
}

Authors: Marcos Fuentes, Hedley Smyth and Andrew Davies.

\section{Highlights:}

- This study identified eight value interactions across the project lifecycle, which may be used to enhance value outcomes for client organisations in the long-term.

- This study examined the implications produced by projects and identified five types of value outcomes that appeared in the long-term.

- This study used the lens of Service Dominant-Logic, which is to date the most relevant lens to explore the co-creation of value outcomes from a client perspective.

- This study may prompt project practitioners to undertake a set of collaborative processes not only to improve benefits for client organisations but also to avoid negative financial consequences. 


\begin{abstract}
Client organisations, as sponsors, owners, and users, face the challenge of generating and delivering value outcomes to a wide range of stakeholders. However, research has demonstrated that projects constantly fall short of providing valuable outcomes to clients in the medium- and long-term. While value outcomes appear in the latter stages of a project, they have a link back to the definition phase of a project, where value outcomes can be purposely identified and designed for the long-term. Value per se has been historically researched from a supplier and financial perspective. In addition to this, research around the client perspective has been scarce, particularly the exploration of the creation of value outcomes for the long-term. To this end, the ServiceDominant Logic is an established framework to analyse the creation of value outcomes in the long-term for a client perspective. This framework is being used in this research to analyse six project case studies from two public sector client organisations in the United Kingdom. The results reveal eight collaborative value interactions, which may enhance a series of value outcomes from a client perspective in the medium- and longterm. Additionally, tensions have been identified during these value interactions, which require management attention to defend the value outcomes. Overall, this study may prompt project practitioners to undertake a set of co-creation practices to formulate projects as service provision and avoid negative impacts to business models.
\end{abstract}

Keywords: Benefits; Business model; Co-creation; Outcomes, Service Dominant-Logic; Value.

\title{
1. Introduction
}

\subsection{Background}

Client organisations face the challenge of creating and delivering value outcomes to a wide range of project stakeholders and, ultimately, to society at large. Thus, clients are particularly interested in what the project can 
do for them in the long-term (Smyth, 2015). It then becomes critical the conceptualisation of project value in the early stages of a business case. One of the challenges when conceptualising value is, for example, dealing with different perceptions of value. Although multiple and conflicting perspectives of value may be found at an early stage of a project, the value outcomes should be (theoretically) anchored to the client, as it is the main stakeholder that absorbs the implications of value outcomes in the long-term. Value outcomes tend to start emerging in the latter stages of a project, yet these have a direct link to the conception of a project (front-end stage), where most of the value can be created, designed and configured (Morris 2013). Once the conceptualisation phase is closed, most of the value outcomes have been locked-up, including the main benefits or sacrifices for the client organisation.

The management of the value outcomes starts at the front-end stage and may continue along the project lifecycle through a series of activities carried out by project stakeholders, such as suppliers, clients, sponsors, operators and users. These stakeholders may mobilise tangible and intangible resources, such as skills, information and expertise, to collaborative co-create value outcomes. However, the management of the value outcomes may vary in practice. Research has shown that the current transactional way of managing value outcomes does not necessarily meet the mandatory client's goals, which ultimately affects end-users and other relevant stakeholders (Aarikka-Stenroos and Jaakkola 2012; Smyth 2015).

Winter et al. (2006) point out that one of the main causes of this ineffective management of value outcomes to clients is due to a traditional supplier and production-oriented approach. This approach is particularly focused on the production of inputs and outputs of engineering systems. Artto et al. (2016, p. 267) argue that the "traditional view of construction projects [is] producing mere physical facilities". This type of tangible output in the short-term has been narrowly considered as value outcomes for the client (cf. Shenhar and Dvir 2007; Chih and Zwikael 2015; PMBOK, 2017). In this article, we argue that value is linked to the functionality and usefulness created by the project particularly for the client in the medium- and long-term. This form of functional value is referred to as value-in-use (see Grönroos and Voima 2013; Grönroos and Gummerus 2014). This functional perspective of value gives rise to the concept of considering projects as rendering a service (in singular) in the long-run.

Previous conceptualisation of services (in plural) (see Zeithaml et al. 1985) view services as outputs or addons to the main production process, such as maintenance or customer service. In that view, services were 
outside the creation of value outcomes. However, an established paradigm in the marketing literature, ServiceDominant Logic (SDL), define service (in singular) as "the application of competencies (knowledge and skills) for the benefit of another entity or the entity itself' (Lusch and Vargo 2014, p. 12). This suggests that the mobilisation and collaborative use and exchange of resources, particularly at an early stage of a project, may enhance the value outcomes for the client in the long-term (Wetter-Edman, 2014) and its competitive advantage in the project business.

The core concept of SDL is value co-creation, which can be referred to as a functional and interactive process to enhance the client' value outcomes as a goal (Grönroos $2011 ; 2017)$. The co-creation of value revolves around value interactions across the project lifecycle, which create a platform where relevant actors may work together to improve the functionality of the value outcomes (Smyth, 2015). Although these value interactions may take place in an early stage of a project, its implications can be observed until the latter stages of a project (Artto et al. 2016).

In summary, Service Dominant Logic is an alternative theoretical perspective, which focuses on the improvement of value outcomes for the client. To do this, a mobilisation of resources during the value (co)creation process may ensure that value outcomes are designed and delivered according to the client's needs (Smyth, 2015; cf. Vargo and Lusch 2016; Grönroos 2017). However, most of the research in the co-creation of value outcomes is based on a conceptual level. Empirical evidence and analysis are needed to understand to what extent it can be applied in project settings (Smyth et al. 2016). Thus, this article empirically explores different value interactions such as co-learning with internal and external stakeholders, co-designing for service experience, co-solving problems and others (see Figure 1). These value interactions may enhance a series of value outcomes in the long-term, such as operational, experiential, social value outcomes. These value interactions may prompt practitioners to undertake a set of co-creation principles for formulating projects as service provision.

\subsection{Research goal and questions}

The main goal of this research was to identify key value interactions across different stages of a project that may directly impact a series of value outcomes in the medium- and long-term. The exploration was carried out using the co-creation lens from the SDL perspective. Although the co-creation lens is the departure point for 
the analysis (Grönroos 2017; Vargo and Lusch 2016), current co-creation assumptions are critically challenged in the context of a project setting as few empirical research using these lenses have been published. To reach this goal, we researched two similar client organisations at the project level. In total, we examined six representative case studies from their project portfolio. While the focus was intentionally placed on the publicsector client organisations in order to understand the implications of the value interactions in the long-term, suppliers and end-users have been approached in order to have an informed perspective on the client's value outcomes. The setting explored is rooted in a Business-to-business context, where the main clients are Higher Education Institutions, such as universities; and end-users are the people using the project resources in the long-term, such as students, academics and professional services staff.

The main unit of analysis to explore the co-creation of value outcomes is the interaction between actors (an Actor-to-Actor approach), as suggested by Grönroos $(2011 ; 2017)$. The client organisation in this research has been placed as the pivotal role in the co-creation process between suppliers and end users. We then posed the following research questions for our exploration:

1. Which types of value interactions occur across the project development sequence from the client perspective?

2. To what extent do the value interactions contribute to achieving the client value outcomes in the medium- and long-term?

ur findings show eight key value interactions, which may enhance a group of value outcomes in the medium- and long-term. In addition to this, several challenges to the concept and application to the process of value cocreation have been set across the paper. Overall, this research unpacks the process of value co-creation for project settings and present eight key value interactions to enhance the value outcomes.

This paper is organised as follows. First, we present a literature review with a focus on the value creation in projects, followed by an exploration of the literature in SDL in marketing. Then, we present the methodology and methods undertaken in this study. Later, the result section shows eight value interactions that may enhance value outcomes in the long-term. This is followed by a discussion section, where results have been critically analysed and compared with related literature. We end up this article by setting out the theoretical contributions, implications for managers and the research limitations. 


\section{Literature Review}

\subsection{Management perspectives on value}

Value has been at the heart of management discussion, for many years, in order to maximise benefits for a wide range of stakeholders, including suppliers, shareholders, clients, and other relevant stakeholders. Due to the competing perspectives of the creation of value, it has resulted in that value is yet an ambiguous area across the management literature (Woodall, 2003). Traditionally, notions of the creation of value have been researched from a supplier perspective (cf. Porter 1985; Barney 1991; Davies 2004). The focus in that perspective is to use the firm's resources, capabilities, and their supply chains to produce valuable products in order to improve the market position. Increasingly, some authors (Aarikka-Stenroos and Jaakkola 2012; Jaakkola and Hakanen 2013) have provided evidence that demonstrates that these types of approaches do not meet the mandatory client's goals and their envisioned value outcomes for the long-term. Other competing perspectives (e.g. Vargo and Lusch 2004; Huemann and Zuchi 2014) argue that clients have been treated as static instruments and are consequently positioned outside of the value-creating process.

A shift of the creation of value from a supplier orientation has been informed across the strategic and marketing literature (cf. Grönroos 1984; Normann and Ramirez 1993; Prahalad and Ramaswamy 2004; Vargo and Lusch 2004). This shift suggests that the creation of value, rather than being largely created by the supplier organisation, it may involve a collaborative process among other relevant stakeholders. Karpen et al. (2011) thus argue that this type of value collaborative approach may ensure the effective management and delivery of value outcomes for the client in the long-term, as clients form part of the process of the creation of value outcomes.

\subsection{Value in the project context}

Since the call from Winter et al. (2006) to address further aspects of the creation of value in the project settings, different perspectives have been discussed. For example, the traditional project perspectives represented by the project management methodologies, such as the PMBOK by the Project Management Institute, largely and narrowly focus on the creation of value during the execution and delivery phase. Other methodologies, such as the IPMA Eye Competence promote a strategic and value-oriented approach at the front-end of projects, 
however, further exploration is required to unpack the concept of co-creation of value in order effectively enhance project value in the long-term.

Academic consensus has been reached that the front-end is a key stage to configure and design value for the short- and long-term (Kim and Wilemon 2002; Williams and Samset 2010; Edkins et al. 2013). However, this consensus may not be reflected in practice. Papke-Shields et al. (2010) found that project practitioners still consider only short-term perspectives of project value. In contrast to this, Lepak et al. 2007 theoretically argue that the implications of a project may extend on an individual, organisational, and societal level for the longterm. For example, Martinsuo and Killen (2014) discussed the social and environmental implications that a project may produce in the ecosystem in the long-term. Yet, the long-term aspects of value have been overlooked both in practice and research.

In project research, much of the work around the creation of value has a largely manufactured and production focus (Winter et al. 2006). While the work of Morris (2013) has extended beyond the short-term perspectives, Smyth et al. (2017) argue that Morris' work is around defining value as inputs: establishing the business case; capturing requirements; developing documentation for sanction, balancing trade-offs, and overall, in choosing the right projects. In a similar manner to Smyth's work, Zwikael and Smyrk (2012) argue that there is a flawed strategic definition of value at the conception of a project, which impedes the connection between the project inputs with the strategic value outcomes in the long-term value.

Long-term perspectives of value have increasingly received attention in project research. For example, Artto et al. (2016) conceptually used a lens of system lifecycle to connect the planning stage of a project with the operations phase. Artto and his colleagues found four value enhancing mechanisms, which can be applied at the front-end to improve the multi-organisational long-term impact. Along the same line of thinking, Matinheikki et al. (2016) found specific network management activities, which may help to shape the long-term interorganizational network. While the long-term implications have been lately addressed, there is a considerable gap in connecting the early stage of a project with its long-term implications (Laursen and Svejvig 2016). To conceptually address this gap, an established paradigm in the literature of marketing: Service-Dominant Logic (Grönroos 2017; Vargo and Lusch 2016) is to date the most relevant framework to explore the design and configuration of value outcomes for the long-term from an early stage of a project. 


\subsection{Projects as service provision}

The theoretical constructs of SDL initially appeared in 2004 in a seminar paper by Vargo and Lusch, with further revisions in 2008 and 2016. In SDL, service revolves around the mobilisation and exchange of static and dynamic resources, such as people, processes, and technologies, to effectively achieve the client's value outcomes in the medium- and long-term (Spohrer et al. 2007; Vargo and Lusch 2016). This service perspective creates a wider perspective on projects beyond the transactional offerings. Recent research on projects has, to some extent, started to explore these service perspectives. For example, Wikström et al. (2010) and Kujala et al. (2011) established business models for different delivery solutions. However, Smyth (2015) argues that their focus is mainly on the solution delivery and disregards the service experience produced by the project in the medium- and long-term. Applying the SDL perspective, Smyth (2015) established two distinct service experience phases in a project: (1) an emergent experience in execution and delivery; and (2) emergent experience through asset receipt and use, in post-completion and beyond. Following Smyth's phases, Fuentes (2018) found that the mismanagement of the service experience may not only destroy the experiential outcomes for clients and users but also negatively affect the business model for the client organisations. Overall, while service perspectives have started to provide alternative and wider perspectives in project studies, "it is not immediately obvious which aspects of the...service[s] literature are relevant (Leiringer and Bröchner 2010, p. 1124). Therefore, there is still a need to further explore aspects of this service related-literature, particularly the core service concept: value co-creation.

\subsection{Co-creation of value in projects}

Value co-creation can be defined as a functional and interactive process to enhance the client' value outcomes as a goal (Grönroos 2011; 2017). Value co-creation goes in line with the thinking that "no project is an island" (Engwall 2003, p. 789), prompting organisations to use the project environment, including external actors, in order to enhance their value outcomes. In SDL, external stakeholders, such as end-users, are useful resource integrators, which may exchange valuable (operant) resources, such as skills, information and expertise (Payne et al. 2008).

To date, there are two competing explanations of the concept of value co-creation. On one side, Vargo and Lusch $(2004 ; 2016)$ argue that a value co-creation process takes place always across an entire project. On the 
other side, Grönroos $(1984 ; 2017)$ argues that co-creation takes place only through direct value interactions and not all times. This study argues that Grönroos' (1984; 2017) perspective on co-creation may provide a better analytical lens to examine project relationships. Project per se are inherently relational and therefore embody interactions. However, it would be unrealistic that an entire project process needs a collaborative approach, as advocated by Vargo and Lusch (2017). So, if value co-creation is worthy only for specific situations, how can a project manager recognise those situations? Luotola et al. (2017) argue that a value cocreation process may be primarily undertaken to face complex and uncertain situations, rather than simple and previously known situations. In these type of situations, the co-creation process may be considered as an alternative solution to solve complex situations.

Co-creation has increasingly received attention in project research. The overall exploration of co-creation has taken divergent routes, such as exploring the micro or macro level, or the implications of the co-creation process. For example, Cova and Salle (2008) focused upon the macro-level aspects of value co-creation. The authors identified a process to co-create value between the suppliers with the customer networks. Other researchers have focused on the micro-level processes and practices (cf. Aarikka-Stenroos and Jaakkola 2012; Jacobsson and Roth 2014; Hellström et al 2016; Luotola et al. 2017). For example, Luotola's et al. (2017) findings show that the co-creation process plays a key role in reaching certainty, particularly for problem-solving negotiations that are handled at the early stage of a project. Other researchers have focused upon the implications of a value co-creation process (cf. Mills and Razmdoost 2016; Fuentes and Smyth 2016; Fuentes 2018). For example, Mills and Razmdoost (2016) found that the mismanagement of relationships and expectations may negatively affect the project outcome and resources in the long-term. But overall, most of the research in projects of the co-creation of value is still at a conceptual level and evidence provided has been limited (see Table 1). Therefore, there is a need to continue exploring the co-creation process to understand what aspects could be useful to project settings. 


\begin{tabular}{|c|c|c|c|c|}
\hline Authors & Context & Methods & Discipline & Key empirical contribution \\
\hline $\begin{array}{l}\text { Cova and } \\
\text { Salle (2008) }\end{array}$ & $\begin{array}{l}\text { Application of a co-creation lens to } \\
\text { understand the transition from products to } \\
\text { service. }\end{array}$ & $\begin{array}{l}\text { Qualitative research } \\
\text { through two case } \\
\text { studies. }\end{array}$ & $\begin{array}{l}\text { Industrial } \\
\text { Marketing } \\
\text { Management }\end{array}$ & $\begin{array}{l}\text { Identification of a process to co-create value between the } \\
\text { supplier's networks with the customer's networks, linked } \\
\text { through the value proposition in B2B strategies. }\end{array}$ \\
\hline $\begin{array}{l}\text { Aarikka- } \\
\text { Stenroos and } \\
\text { Jaakkola } \\
(2012)\end{array}$ & $\begin{array}{l}\text { Application of a co-creation lens to } \\
\text { understand the activities and resource } \\
\text { exchange between buyers and suppliers in } \\
\text { co-problem solving situations. }\end{array}$ & $\begin{array}{l}\text { Qualitative research } \\
\text { through an intense } \\
\text { interviewing process. }\end{array}$ & $\begin{array}{l}\text { Industrial } \\
\text { Marketing } \\
\text { Management }\end{array}$ & $\begin{array}{l}\text { Identification of specific roles assigned to suppliers and } \\
\text { customers, as well as the critical resources they need to } \\
\text { facilitate the co-problem solving process. }\end{array}$ \\
\hline $\begin{array}{l}\text { Chang et al. } \\
(2013)\end{array}$ & $\begin{array}{l}\text { Conceptualising projects as a process of } \\
\text { value (co-)creation in the long-term. }\end{array}$ & $\begin{array}{l}\text { Qualitative research } \\
\text { through three case } \\
\text { studies. }\end{array}$ & $\begin{array}{l}\text { Infrastructure } \\
\text { Project } \\
\text { Management }\end{array}$ & $\begin{array}{l}\text { Findings highlight the importance of stakeholder engagement } \\
\text { to balance the needs and other contextual forces in the co- } \\
\text { creation process. They also argue that project success needs } \\
\text { broadening to consider the value created and captured. }\end{array}$ \\
\hline $\begin{array}{l}\text { Liu et al. } \\
(2014)\end{array}$ & $\begin{array}{l}\text { Application of a co-creation lens between the } \\
\text { client and the contractor at the front-end of a } \\
\text { project. }\end{array}$ & $\begin{array}{l}\text { Qualitative research } \\
\text { on a single case } \\
\text { study. }\end{array}$ & $\begin{array}{l}\text { Infrastructure } \\
\text { Project } \\
\text { Management }\end{array}$ & $\begin{array}{l}\text { Findings indicate that external actors may exchange valuable } \\
\text { resources e.g. knowledge and expertise at the front-end to } \\
\text { provide common grounding in the decision-making process. }\end{array}$ \\
\hline $\begin{array}{l}\text { Jacobsson } \\
\text { and Roth } \\
(2014)\end{array}$ & $\begin{array}{l}\text { Exploration of a partnering project to } \\
\text { understand how a co-creation lens may } \\
\text { influence the production focus. }\end{array}$ & $\begin{array}{l}\text { Qualitative research } \\
\text { on a single case } \\
\text { study. }\end{array}$ & $\begin{array}{l}\text { Construction } \\
\text { Project } \\
\text { Management }\end{array}$ & $\begin{array}{l}\text { Findings show that interactions may create an engagement } \\
\text { platform, which may enhance dialogue, access and risk } \\
\text { assessments. However, a shift in the mindset of practitioners } \\
\text { needs to occur to make this platform work. }\end{array}$ \\
\hline $\begin{array}{l}\text { Mills and } \\
\text { Razmdoost } \\
(2016)\end{array}$ & $\begin{array}{l}\text { Application of a co-creation lens to explore } \\
\text { the relationships and the value formation } \\
\text { process. }\end{array}$ & $\begin{array}{l}\text { Qualitative research } \\
\text { on a longitudinal } \\
\text { study. }\end{array}$ & $\begin{array}{l}\text { Construction } \\
\text { Project } \\
\text { Management }\end{array}$ & $\begin{array}{l}\text { Evidence highlights that value co-creation is highly linked } \\
\text { with positive aspects. However, the mismanagement of the } \\
\text { relationship and expectations may create a co-destruction of } \\
\text { value, negatively affecting project resources. }\end{array}$ \\
\hline $\begin{array}{l}\text { Smyth et al. } \\
(2017)\end{array}$ & $\begin{array}{l}\text { Application of a co-creation lens to examine } \\
\text { project value beyond the traditional input and } \\
\text { output performance. }\end{array}$ & $\begin{array}{l}\text { Single and } \\
\text { interpretive case } \\
\text { study based on } \\
\text { secondary data. }\end{array}$ & $\begin{array}{l}\text { Infrastructure } \\
\text { Project } \\
\text { Management }\end{array}$ & $\begin{array}{l}\text { Findings indicate that long-term implications are overlooked } \\
\text { in the decision-making process at the front-end, which is } \\
\text { focused upon the traditional project success criteria: time- } \\
\text { cost-quality/scope. }\end{array}$ \\
\hline $\begin{array}{l}\text { Luotola et al. } \\
(2017)\end{array}$ & $\begin{array}{l}\text { An exploration of a co-creation lens, } \\
\text { combined with design thinking, in a selling } \\
\text { process. }\end{array}$ & Action-research. & $\begin{array}{l}\text { Industrial } \\
\text { Marketing } \\
\text { Management }\end{array}$ & $\begin{array}{l}\text { Findings show that the co-creation process plays a key role } \\
\text { in reaching certainty, particularly for problems during the } \\
\text { negotiations handled at the front-end stage. }\end{array}$ \\
\hline $\begin{array}{l}\text { Fuentes } \\
\text { (2018) }\end{array}$ & $\begin{array}{l}\text { Application of a co-creation lens, combined } \\
\text { with service design thinking (tools), to explore } \\
\text { the destruction of experiential outcomes. }\end{array}$ & $\begin{array}{l}\text { Qualitative research } \\
\text { on a single case } \\
\text { study. }\end{array}$ & $\begin{array}{l}\text { Construction } \\
\text { Project } \\
\text { Management }\end{array}$ & $\begin{array}{l}\text { Findings show how the silos mismanagement of the service } \\
\text { experience may destroy the experiential outcomes for users } \\
\text { and in turn affect the financial outcomes for the client } \\
\text { organisation. }\end{array}$ \\
\hline
\end{tabular}


Table 1. Key empirical studies using a co-creation lens linked to project contexts. 
While the exploration of this process may take divergent avenues, several authors (Leroy et al. 2013; Storbacka et al., 2016; Foss and Pedersen 2016) argue that the micro level foundations have been prematurely blackboxed by the SDL initiators: Vargo and Lusch. In fact, Grönroos' (2017:125) states: "to develop a managerially relevant understanding of value and [co-]value creation, these phenomena must be analysed on a micro level". This statement sounds logical in the project context as specific management actions and activities that create value have been insufficiently specified in the relationship marketing and collaboration school of thought (cf. Prahalad and Ramaswamy 2004; Ballantyne and Very 2006; Smyth and Pryke 2008; Cova and Salle 2008). To address this key gap, the main goal of this research is being to identify value interactions (as key management activities) that may directly impact a series of value outcomes in the medium- and long-term.

\section{Research Methodology and Methods}

\subsection{Research context}

The empirical context of this research is set in two UK public sector organisations: Higher Education Institutions (HEI). Projects in this sector include the provision of new facilities, infrastructure, and other IT systems around the university services. The universities (as client organisations) play a pivotal role, within a Business-toBusiness (B2B) setting, mediating and co-creating value between the supplier organisations and their enduser base, including the students, academics and professional service staff. It is fair to state that this sector (context) may be considered exceptional, as projects in this sector are reasonably considered as straightforward in comparison to others complex settings. However, key aspects are found in this sector in relation the provision of service. The client organisation is part of the user base; thus the client plays an important role in the conception and perception of value outcomes. The perception of value outcomes from their user base is critical, as it forms part of the brand of the organisation, which in turns to help to maintain, improve, or damage their market position. Thus, this research setting may be considered appropriate for exploring the generation of value outcomes and its implications in the long-term by using a co-creation lens (Vargo and Lusch 2017).

We considered two client organisations with a focus on their project teams. Both client organisations are well positioned in the HEl sector and face the challenge of creating and delivering well-perceived value outcomes 
to improve their brand and market position. Both universities have recently undertaken a series of projects under investment programmes to meet user demands (see Table 2). Overall, six case studies were explored at the project level, specific details of each organisation are explored in Table 2 and 3.

\begin{tabular}{|l|l|l|l|l|l|l|}
\hline Item & $\begin{array}{l}\text { UK } \\
\text { public } \\
\text { sector }\end{array}$ & $\begin{array}{l}\text { Number of } \\
\text { users } \\
\text { (approx.) }\end{array}$ & $\begin{array}{l}\text { Investment in a } \\
\text { build and } \\
\text { systems } \\
\text { programme } \\
\text { Status }\end{array}$ & $\begin{array}{l}\text { Sector } \\
\text { Ranking }\end{array}$ & $\begin{array}{l}\text { User experience } \\
\text { ranking, } \\
\text { according to } \\
\text { national } \\
\text { surveys }\end{array}$ & $\begin{array}{l}\text { Number of } \\
\text { case } \\
\text { studies } \\
\text { carried out }\end{array}$ \\
\hline $\begin{array}{l}\text { Client } \\
\text { Organisation } \\
\text { A }\end{array}$ & $\begin{array}{l}\text { Higher } \\
\text { Education } \\
\text { Institution }\end{array}$ & 25,000 & $\begin{array}{l}\text { £275 million / } \\
\text { Completed }\end{array}$ & $\begin{array}{l}\text { Top 10 } \\
\text { Nationwide }\end{array}$ & Tier 1 & 1 \\
\hline $\begin{array}{l}\text { Client } \\
\text { Organisation } \\
\text { B }\end{array}$ & $\begin{array}{l}\text { Higher } \\
\text { Education } \\
\text { Institution }\end{array}$ & 50,000 & $\begin{array}{l}\text { £1.2 billion / } \\
\text { Ongoing }\end{array}$ & $\begin{array}{l}\text { Top 10 } \\
\text { Worldwide }\end{array}$ & Tier 3 & 5 \\
\hline
\end{tabular}

Table 2. Overview of the two client organisations researched

\subsection{Research methodology and design}

All projects are located in a social and open system (Konstantinou and Müller 2016), in which the social reality of these may be considered as multi-layered (Bhaskar 2008). The multi-layered perspective means that while project events are observed and experienced by stakeholders in everyday practices, they are triggered by deeper casual generative processes, which are structured through enduring properties (Danermark et al. 2002). Thus, to explore the deeper reality of project events, we adopted a critical realism (CR) philosophy to understand the hierarchically ontological domains of the reality: the empirical, the actual and the real domain (Bhaskar 2008). Researchers argue that CR produces stronger scientific explanations over a phenomenon compared to other traditional perspectives because it looks at the root cause of the events (Wuisman 2005; Isaksen 2016; Smyth and Morris 2007). Thus, we employed CR to explain the rationale, effects, and consequences of the co-creation of value outcomes in projects.

To explore the co-creation phenomenon, we adopted a qualitative approach using a multiple-case strategy of six case study projects (Denzin and Lincoln 2000). Project case study 1 was set up as a prelude (exploratory) case within organisation A (Yin 2017). This project case study represented a key investment within the project portfolio to achieve the IT mobility strategy within the university. The senior management team prioritised this project and provided adequate resources to it. The practices undertaken for this project might be a representation of practices in other key projects within organisation $\mathrm{A}$. We then decided to explore other key projects in a different organisation. Organisation B provided exceptional access to examine key five project case studies from its project portfolio. This then allowed us to compare project practices of similar 
organisations. While the focus of this research was on the project case study level, the nested approach (Yin, 2017) taken in organisation B allowed us to gain an in-depth understanding of both the historical and organizational context (Engwall 2003). The context of each project case study, including its key features, can be seen in Tables 3 and 4. Overall, we conducted a cross-case comparison of the emergent insights from the theoretical explanations (Eisenhardt and Graebner 2007), as seen in Table 5.

For all project case studies and according to CR (Bhaskar 2008), we sought theoretical explanations addressing the context, the outcomes and its causalities (Smyth and Morris 2007; Wynn and Williams 2012). Two streams were taken for this task. Firstly, we explored project case studies, from case 1 to 5 , in retrospective accounts. The main aim of this was to examine the value interactions across the project stages and emergent value outcomes in the medium- and long-term. Secondly, we explored project case study 6 in prospective accounts over a one-year period. The latter enabled us to reveal the dynamics of the phenomena in real time. Although we do not consider the engagement in the prospective study as ethnographic, this engagement enabled us to further understand the historical and organizational context in organisation $\mathrm{B}$.

\subsection{Methods of data collection}

The data collection was carried out through semi-structured interviews. In total, fifty-nine interviews were conducted across the six project case studies (see table 3). Key participants from the formal structure of each project were initially selected. Then, we used a snowballing sampling to complement the initial set of actors. To ensure conformability in the study, we used the same question protocol across all interviews. The interview questions were structured in relation to the project stages, which facilitated the organisation of data. The core themes established in the interviews were:

- The exploration of the (actor-to-actor) value interactions from the client perspective during the: (1) preproject stage, to understand how value propositions were configured and designed; (2) mid-project stage, to understand how value outcomes were finessed after the initial planning; and (3) post-completion stage, to understand the emergence of value outcomes.

- The implications of the value interactions in the long-term and the perception of the value outcomes from the client perspective.

- The organisational context to understand enablers and constraints, both of which influenced the value interactions and its implications. 
- Lessons learned of each project to explore both positive and negative insights.

We kept notes for each interview and observation to keep record of emergent ideas and the cognitive aspects during the engagement (Emerson et al. 2001).

\subsection{Data analysis}

For the analytical unit of analysis, following Grönroos' (2017) suggestions, we used Actor-to-Actor (A2A) approach at the project level with a particular focus on the clients' value outcomes. This facilitated the analytical exploration of the value interactions. As part of the initial stage of analysis, we familiarised ourselves with our primary and secondary data by re-listening to audio-recordings and re-reading audio-transcripts and reviewing additional secondary documentation.

We mainly analysed the data using the following four steps. First and in line with critical realism (Bhaskar 2008), we explored the data deductively using the following sensitising categories (Van de Ven and Poole 2005) coming from the main concepts of value co-creation: (1) direct interactions; (2) outcomes; (3) value; (4) service; (5) impact (6) context; (7) benefits. As a second step, we introduced openness in the exploration by inductively extracting other relevant data in relation to the research questions. The extraction of these data concerned the challenging aspects of co-creation, including project sacrifices, destruction practices, disconnection of interactions, and a wider set of outcomes beyond the experiential nature strongly advocated by Vargo and Lusch (2016). This extraction was in line with other researchers' perceptions (Echeverri and Skålén 2011, Leroy et al. 2013; Storbacka et al. 2016; Mills and Razmdoost 2016), which argue that much of the work in relation to value co-creation is rooted in a positive tone, that, in turn, limits the critical analysis of this phenomena. We then organised all these data in a database to create initial patterns from the empirical level.

The initial interpretation of this set of data resulted in two main blocks: (1) the context of the value interactions; (2) a number of value interactions across project stages; (3) the implications of the value interactions in the long-term. However, according to Bhaskar's (2008) ontology, all this initial interpretation formed part of the empirical level of the reality. Therefore, as a third step, we moved from the empirical level to the real level by applying retroduction (Danermark et al. 2002). As a final step, we synthesised the overall results from the retroduction analysis in a similar fashion to Gioia et al. (2013), which can be seen in Appendix 1. 


\begin{tabular}{|c|c|c|c|c|c|}
\hline \multicolumn{6}{|c|}{ Description of case studies } \\
\hline $\begin{array}{l}\text { Project } \\
\text { Characteristi } \\
\text { cs }\end{array}$ & Case Study 1 & Case Study 2 & Case Study 3 & Case Study 4 & Case \\
\hline $\begin{array}{l}\text { Organisation } \\
\text { Type }\end{array}$ & $\begin{array}{l}\text { UK Public Sector } \\
\text { Organisation A }\end{array}$ & $\begin{array}{l}\text { UK Public Sector } \\
\text { Organisation B }\end{array}$ & & & \\
\hline Project type & $\begin{array}{l}\text { Wired/Wireless } \\
\text { Internet Service. }\end{array}$ & $\begin{array}{l}\text { Managed Printing } \\
\text { Service }\end{array}$ & $\begin{array}{l}\text { Building } \\
\text { Refurbishment of a } \\
\text { Residence Hall }\end{array}$ & $\begin{array}{l}\text { High Performance } \\
\text { Computing }\end{array}$ & \\
\hline $\begin{array}{l}\text { Start and } \\
\text { completion } \\
\text { date }\end{array}$ & $\begin{array}{l}\text { Early } 2012 \text { - Summer } \\
2014\end{array}$ & Throughout 2013 & Throughout 2015 & Throughout 2015 & \\
\hline $\begin{array}{l}\text { Contract } \\
\text { Value }\end{array}$ & $\begin{array}{l}\text { Approx. £2m over a } \\
\text { 4-year contract. }\end{array}$ & $\begin{array}{l}\text { Contract based on } \\
\text { service usage of } \\
\text { approx. } 600 \text { managed } \\
\text { devices. }\end{array}$ & Below £164K & Approx. £1.2m & \\
\hline $\begin{array}{l}\text { Evaluation at } \\
\text { project level } \\
\text { during }\end{array}$ & $\begin{array}{l}\text { Front-End } \\
\text { Execution } \\
\text { Post-Completion }\end{array}$ & $\begin{array}{l}\text { Front-End } \\
\text { Execution } \\
\text { Post-Completion }\end{array}$ & $\begin{array}{l}\text { Front-End } \\
\text { Execution } \\
\text { Post-Completion }\end{array}$ & $\begin{array}{l}\text { Front-End } \\
\text { Execution } \\
\text { Post-Completion }\end{array}$ & $\begin{array}{l}\text { Fron } \\
\text { Exec } \\
\text { Post }\end{array}$ \\
\hline $\begin{array}{l}\text { Observing } \\
\text { process }\end{array}$ & $\begin{array}{l}\text { On retrospective } \\
\text { accounts }\end{array}$ & $\begin{array}{l}\text { On retrospective } \\
\text { accounts }\end{array}$ & $\begin{array}{l}\text { On retrospective } \\
\text { accounts }\end{array}$ & $\begin{array}{l}\text { On retrospective } \\
\text { accounts }\end{array}$ & \\
\hline Unit analysis & Actor-to-Actor interactio & in the project level, with & a focus on the client valu & outcomes. & \\
\hline $\begin{array}{l}\text { Method of } \\
\text { analysis }\end{array}$ & $\begin{array}{l}\text { Qualitative content ana } \\
\text { participants and extern }\end{array}$ & $\begin{array}{l}\text { sis and application of } r \\
\text { researchers. }\end{array}$ & oduction (DREIC) mode & rom Bhaskar (2008). Dis & \\
\hline $\begin{array}{l}\text { Number of } \\
\text { semi- } \\
\text { structured } \\
\text { interviews } \\
\text { conducted }\end{array}$ & $\begin{array}{l}\text { Overall: } 17 \\
\text { Breakdown: } \\
\text { a) Client reps: } 12 \\
\text { b) Supplier reps: } 3 \\
\text { c) User reps: } 2\end{array}$ & $\begin{array}{l}\text { Overall: } 7 \\
\text { Breakdown: } \\
\text { a) Client reps: } 6 \\
\text { b) Supplier reps: } 0 \\
\text { c) User reps: } 1\end{array}$ & $\begin{array}{l}\text { Overall: } 6 \\
\text { Breakdown: } \\
\text { a) Client reps: } 4 \\
\text { b) Supplier reps: } 0 \\
\text { c) User reps:2 }\end{array}$ & $\begin{array}{l}\text { Overall: } 11 \\
\text { Breakdown: } \\
\text { a) Client reps: } 9 \\
\text { b) Supplier reps: } 1 \\
\text { c) User reps: } 1\end{array}$ & $\begin{array}{l}\text { Over } \\
\text { Brea } \\
\text { a) } \mathrm{Cl} \\
\text { b) } \mathrm{Si} \\
\text { c) } \mathrm{Us}\end{array}$ \\
\hline Interviewees & $\begin{array}{l}\text { Client reps: } \\
1 \text { Chief Information } \\
\text { Officer } \\
1 \text { Head of } \\
\text { Procurement } \\
\text { 1 Project/Programme } \\
\text { Manager } \\
1 \text { Project Manager } \\
\text { (Operations } \\
\text { Readiness) } \\
1 \text { Head of Networks } \\
1 \text { Legal Manager } \\
1 \text { Head of Service } \\
\text { Delivery and } \\
\text { Partnerships } \\
1 \text { Technical Lead LAN } \\
1 \text { Technical Lead Wi- } \\
\text { Fi } \\
1 \text { Head of Buildings } \\
1 \text { Campus Services } \\
\text { Manager } \\
1 \text { Residence Security } \\
\text { Manager } \\
\\
\text { Supplier reps: } \\
1 \text { Supplier Commercial } \\
\text { Manager } \\
1 \text { Supplier Marketing } \\
\text { Director } \\
1 \text { Supplier Project } \\
\text { Manager }\end{array}$ & $\begin{array}{l}\text { Client reps: } \\
1 \text { Chief Information } \\
\text { Officer } \\
1 \text { Head of } \\
\text { Procurement } \\
1 \text { Senior } \\
\text { Procurement Manager } \\
1 \text { Service Owner } \\
1 \text { Head of IT Asset } \\
\text { and Supplier } \\
\text { Management } \\
1 \text { Customer Relations } \\
\text { Manager } \\
\text { User reps: } \\
1 \text { End-user }\end{array}$ & $\begin{array}{l}\text { Client reps: } \\
1 \text { Head of } \\
\text { Procurement } \\
1 \text { Senior } \\
\text { Procurement Manager } \\
1 \text { Procurement Officer } \\
1 \\
\text { Residence } \\
\text { Manager } \\
\\
\text { User reps: } \\
2 \text { End-users }\end{array}$ & $\begin{array}{l}\text { Client reps: } \\
1 \text { Chief Information } \\
\text { Officer } \\
1 \text { Project Board Chair } \\
1 \text { Head of } \\
\text { Procurement } \\
1 \text { Director of IT } \\
\text { Services } \\
1 \text { Senior } \\
\text { Procurement Manager } \\
1 \text { Senior Project } \\
\text { Manager } \\
1 \text { Project Manager } \\
1 \text { Technical Lead } \\
1 \text { Senior Network } \\
\text { Engineer } \\
\text { Supplier reps: } \\
\text { 1 Supplier Business } \\
\text { Development Manager } \\
\text { User reps: } \\
1 \text { End-User }\end{array}$ & $\begin{array}{l}\text { Clier } \\
1 \mathrm{Ch} \\
\text { Offic } \\
1 \mathrm{He} \\
\text { Proc } \\
1 \text { Dir } \\
\text { Serv } \\
1 \mathrm{Se} \\
\text { Proc } \\
1 \mathrm{Se} \\
\text { Man } \\
1 \mathrm{Te} \\
\text { Supp } \\
1 \mathrm{Su} \\
\text { Man } \\
\text { User } \\
2 \mathrm{En}\end{array}$ \\
\hline
\end{tabular}




\begin{tabular}{|l|l|l|l|l|l|}
\hline & $\begin{array}{l}\text { User reps: } \\
\text { 2 End-User }\end{array}$ & & & \\
\hline $\begin{array}{l}\text { Average time } \\
\text { of interview }\end{array}$ & 40 minutes & 35 minutes & 30 minutes & 41 minutes & 36 m \\
\hline $\begin{array}{l}\text { Secondary } \\
\text { data }\end{array}$ & $\begin{array}{l}\text { Complementary data including: project and procurement documentation, service complaints, organisations' } \\
\text { minutes, service review minutes, emails, social networks, consultancy reports, newspapers and field notes. }\end{array}$ \\
\hline
\end{tabular}

Table 3. Description of the six project case studies

\title{
Context of case studies
}

\begin{abstract}
Case
Study

The client organisation was struggling to meet the IT demands from the student's community, particularly at the re \#1 upgrade the current IT infrastructure to accommodate Wi-Fi service demands in the halls. This project was key to the university. The university, as the client organisation, decided outsourced the implementation, management, an of all its student residences. This project case study was relevant for exploration due to the multiple value interacti users across the project stages. The interactions enabled shaping the specification during the procurement stage. users reported a poor service in the halls.
\end{abstract}

Case $\quad$ The client organisation had an urgency to consolidate a fragmented printing service across its faculties. Thus, the Study to outsource and consolidate a sustainable management plan for this service. This project is relevant for exploratic \#2 nine-month period of procurement negotiation. However, during the operations phase, the user base complained a mismanagement of the service continued throughout the life of the contract to the point that the client organisation it.

Case Due to a natural damage caused by a storm day, a residence hall owned by the client organisation urgently neede Study organisation decided to carry out a project to refurbish it. The initial planning stage carried out by the project team \#3 $\quad$ users. These were relevant stakeholders as they were living in the residence. Overall, the project team failed to re users and it resulted in a poor living experience during the refurbishment for the end-users. As part of the outcome which resulted in a financial compensation of $£ 300,000$ and a considerable delay of the project completion. This pr the co-destruction of value.

Case $\quad$ The client organisation had to replace aging capacity and end-of-life support of a high performance computing sys Study suitable supplier to implement a new system for the client organisation. This case study is relevant for exploration \#4 before the start of the procurement between the client organisation and the potential suppliers. These interactions resulted in positive implications during the operations phase.

Case

Study

The client organisation had the urgency to keep control of research project resources (approx. £150m) across the \#5 to co-develop and implement a Software as-a-Service system to manage the portfolio of research projects. This ce that the client organisation held with the supplier and end-users to co-develop the system. While the project report unexpected business change in the organisation was reported. This ultimately affected the service experience of th

Case

Due to the constant expansion of the university, it was struggling to manage the soft facilities management e.g. wa Study including academic buildings, laboratories, and halls of residence. Thus, a project was set-up to outsource an unifi \#6 management. In contrast to the project case studies from 1 to 5 , which were explored in retrospective accounts, th enabled the explorations of the dynamics of value co-creation in real time, which could not be perceived in the oth

Table 4. Context of case studies 


\subsection{Data quality}

In general, qualitative studies present limitations, such as bias, subjectivity, and methods of data collection (Denzin and Lincoln 2000). To overcome this, this study undertook the following actions to enhance the validity, reliability, and credibility of this research. Firstly, to enhance the research validity, this research used a collection and triangulation of different sources, including primary and secondary data, such as project and procurement documentation, service complaints and websites. This helped us to examine the reality to the best approximation (Yin 2017). In addition to this, this research provides sufficient background information about the six project case studies. Furthermore, we used a consistent protocol of interview questions for all participants during the data collection process. Secondly, to enhance the research reliability, we audiorecorded the interviews. Transcriptions were then carried out and organised in a database. Finally, to enhance the research credibility, we engaged with participants from Organisations $A$ and $B$ in a post-analysis to discuss findings. Feedback was gathered and incorporated into the results. This helped us to create the most accurate representation of reality (Lincoln and Guba 1985). In addition to this, peer scrutiny of this project was carried out through direct discussions with seven researchers from both the project management and marketing school, including Prof. Wikström and Prof. Artto, Prof. Grönroos. Finally, we covered previous literature in relation to our findings to understand comparability, transferability, and the limitations of our results.

\section{Results}

This section focuses particularly on the value interactions that may enhance the value outcomes in the long-term. The value interactions have been grouped in phases, which might provide an indication of a process by which value outcomes could be managed as an integrated approach. In Phase 1, value interactions are meant to identify and understand strategic value propositions. In Phase 2 , value interactions are meant to design and configure value propositions for the medium- and long-term. In Phase 3, value interactions are meant to refine and deliver value outcomes during the execution and delivery phase. Lastly, in Phase 4, value interactions are meant to manage and realise emergent value outcomes post-project completion. The result section is then structured as follows. First, the perception of value outcomes in the long-term is explored. Then, eight value interactions are presented within the four phases of the management of value outcomes. The section ends with a cross- 
tabulation of the value interaction themes against the project case studies, which provides an overarching view of the results.

\subsection{Lack of thinking about value outcomes}

While the focus of this research was on the value outcomes, it became clear in the analysis that project stakeholders had a lack of thinking about the value outcomes in the long-term. One participant in organisation B summarised the perception of value as:

"There is a large and disturbing ignorance around [the organisation], as to what is meant by value, if you go to any professional service... they have a different conception of it".

(Head of Procurement - Case Study 2)

The evidence shows project stakeholders may have disparate perceptions of value, which may complicate the project's definition. For example, some actors consider tangible delivery, such as an IT system, as the main value outcome. This suggests that project teams underplay the perception of value through receipt and use, which demonstrates a lack of thinking about value outcomes in the long-term. Across the six projects case studies, including the analysis of the written business cases, the analysis demonstrates project practitioners place a strong emphasis: (1) upon the successful delivery of manufactured goods; and (2) upon increasing transactional efficiency through cost reduction. To exemplify this, in project case study 1 , the procurement team, who tendered the project, was granted the Best value-for-money award for the outstanding cost-saving negotiation reached during the procurement stage. Yet, users complained about the quality of the service only a year after delivery. One client representative reflected on the short-term approach undertaken by the team in this project as follows: "[The] service was cr*p...l am talking about Wi-Fi and about the whole package...the project was about the cheap" (Technical Lead - Case Study 1). This indicates that project stakeholders reward projects for short-term value outcomes, which are usually about financials and undervalue the long-term perspectives of value beyond the immediate service experience. In contrast to this, the following sections explore key value interactions that may enhance value outcomes in the long-term.

\subsection{Phase 1: Identifying and understanding envisioned strategic value outcomes}

The evidence suggests that strategic value outcomes need identification by backcasting the desirable value outcomes, from the future (operations) to the present (front-end stage). This phase aids in the understanding 
of overall goals, expectations and needs around the future service. We found three specific value interactions that may enhance the client value outcomes in the long-term: (1) co-learning with internal and external stakeholders; (2) co-revealing an existing service system; and (3) co-aligning strategic needs and expectations. These value interactions are explored in the following sub-sections.

\subsubsection{Co-learning with internal and external stakeholders}

The evidence indicates that client project teams used this value interaction as a form of an absorptive learning process, with internal and external stakeholders, such as suppliers and users. This interaction was found useful by project teams during complex and uncertain situations, particularly during the front-end stage. For example, in project case study 4, the project team recognised elements of uncertainty in the technical design. The team decided to learn lessons from a previous project undertaken by another client in the same sector. The perception of this learning interaction was as follows:

He [another client] had run a tender himself, and he came down to the meetings [with the potential suppliers], and had a look at our tender documents and suggested some improvements and some alterations...but, sometimes we had to say no to him, he was a bit pushy sometimes.

$$
\text { (Project Manager - Case Study 4) }
$$

The analysis shows the client organisation was able to learn in an implicit form and explicit form. Firstly, the project team received implicit knowledge from the other client as his experience was considered useful during the development of the specification. In an explicit form, the client made available previous tender documentation to the project team and provided written feedback on the initial specification. While this interaction demonstrates that actors in the ecosystem may be a source of value, in the form of information, expertise, and knowledge, this interaction may have a tipping point, in which the interaction would need to be stopped. For example, during the same interaction, the other client was inclined towards project requirements for the initial tender. However, the other client did not understand the project team's contextual contingencies. Thus, the client senior project manager decided to enforce an immediate halt in this learning interaction to secure the client value outcomes. This suggests that providing full empowerment to co-creators may be dangerous and may lead to co-destruct value instead.

In contrast to the usefulness of this interaction presented in project case study 4 , in project case study 6 , the Commercial Manager reflected on the lack of this type interaction during the project: "One of the lessons here, 
is I don't think our team have picked the good lessons from other universities, there was a need to look wider and not looking inside and in what [the client representatives] know, because [the client reps] are not the keepers of all the knowledge". Particularly in that contract, there were uncertain elements in the environmental outcomes, such as waste collection and sustainability practices, which could have been learned from other client organisations who had already completed a similar project (as noted in project case study 4). This might have helped the project team to avoid erroneous management from an early stage of a project.

\subsubsection{Co-revealing existing service systems}

The evidence indicates that this type of interaction was used when the client organisation was dealing with uncertainty about an existing service system, including its processes and service functionality. For example, in project case study 1 , the project sponsor wanted to explore the delivery capability of the suppliers as claimed in their tender responses. Thus, the client carried out site visits to explore their existing systems. The exploration was possible because the supplier used a repeatable solution across a variety of clients. Thus, operational outcomes were observable as they were already functioning for other similar clients. Representatives were able to look at the tangible and intangible aspects of a service during the operations phase. For example, from a tangible perspective, client representatives were able to "look at how [the supplier] performed their [internal] processes and how they standardised them" (Head of Networks - Case Study 1). From an intangible perspective, one representative stated:

"it was good to see the staff if they were approachable, it was a good feeling, you can't score on that but you understand the culture of the company"

(Programme Manager IT - Case Study 1).

As a result of this interaction, the client organised reduced project uncertainty as they were able to understand the delivery capability (tangible aspects), but also was able to experience some of the intangible aspects, such as the organisational culture.

\subsubsection{Co-aligning strategic needs and expectations}

The evidence indicates that client organisations used this type of interaction to explore a specific product or service in the market or to match the client's strategic needs and expectations, particularly with the suppliers. It was found that management activities, such as early engagement sessions, market consultations, supplier 
briefings, supplier demonstrations and user workshops, may help to align the needs and expectations of value outcomes from an early stage of a project. While these forms of interactions have been undertaken in the project business for a number of years, we particularly found one challenge during this value interaction. For example, in project case study 1, the client organised early engagement sessions with all pre-qualified suppliers in a single session. However, the interaction was not perceived as useful by the client nor the suppliers. One supplier's Commercial Manager stated,

"We could not talk [during the session] and give our [technical and commercial] ideas on how we deliver our service because that would be unique to us".

(Supplier Commercial Manager - Case Study 1)

This suggests that clients and suppliers need to be aware of the commercial risks taken during the process of co-creation, as it might endanger their market position and business model.

\subsection{Phase 2: Designing and configuring value propositions}

According to the evidence, once the strategic value propositions have been identified and agreed by senior stakeholders, project teams could then design and configure value propositions. In this phase, we found two specific value interactions across our cases that may enhance the value outcomes in the long-term: (1) codesigning for service experience; and (2) co-developing a service, which are explored in the following sections.

\subsubsection{Co-designing for service experience}

This value interaction may enable a project team to design: (1) the service experienced during execution; and (2) the service rendered during post-completion. To illustrate service experienced during execution, in project case study 3 , the client organisation (university) decided to carry out a refurbishment of a hall of residence. However, the client failed to anticipate the service experience that this project would cause to students during the project execution. The students who were living at the residence at the time of the refurbishment found the construction works disrupting their activities. This "caused mental and physical discomfort" (End-User - Case Study 3). This service experience resulted in student strike action, which ended with a compensation of $£ 300,000$ to the students (Times Higher Education 2015; The Guardian 2017). This demonstrates how functional silos when designing a service experience are insufficient. In contrast, boundary-spanning interactions are important to create value, in terms of service experience. 
To illustrate the service rendered during post-completion, the evidence shows that projects create preconditions to influence routines and processes in the operations phase. For example, in project case study 5 , when the client organisation delivered a new software system, it flipped an organisational process in the operations phase. This result was reflected by one participant as follows:

"We did not spend a lot of time looking at the services team, they struggle [now] internally with their own business change, which is a point for the lesson learned. We did not spend much time with them and only now we are getting on top of that"

(Senior Project Manager - Case Study 5)

This new but desynchronised process led to ineffective service, disappointing the user stakeholders. It is being until now (operations phase) that the service design, including the system functionality, is being created by the project team. Overall, evidence across the six case studies shows an absence of this value interaction, which not only results in destroying a service experience but also in an affected business model and organisational routines.

\subsubsection{Co-developing a service with agility}

According to the data, this type of interaction refers to developing a service, including its tangible and intangible elements, with agility across the project phases. For example, in the case study 5 , a new IT system had to be developed from scratch as no solutions were available in the market. Thus, the client decided to award a contract, to co-develop a software-as-a-service. During the front-end of the project, the client and supplier acknowledged technical uncertainty to develop this system. To reduce uncertainty, the Senior Project Manager reported workshops were carried out with twenty end-users where functionality scenarios were explored. Then, the initial set of requirements were agreed. However, as the project was progressing "[some of] the requirements changed because we were able to know if the supplier could do something or not" (Senior Procurement Manager Case Study 5). While requirements changed, they were agreed monthly through sprint sessions. One participant summarises these sessions:

The sprint sessions helped us to set out a very clear directive on what we were doing and on what we were focusing... so at the beginning of every month, we had a sprint kick-off workshop [with the relevant stakeholders] and part of it was about what was done in the last sprint, we learned from each sprint, and we made sure the change list was signed off or and also to plan what would be done for the next 4 weeks.

(Senior Project Manager - Case Study 5) 
These collaborative sessions between the relevant stakeholders, always including the end-users, help to replan the functionality of the service across the development sequence. However, due to the intense and iterative planning interactions across the development sequence, evidence across cases shows that this agile approach consumed more resources in terms of time and human capital. For example, surprisingly, it was reported that the project board chair in this project attended to the monthly co-development sessions to accelerate the process of changes. This contrasts with other project case studies, in which project board chairs only acted as a gatekeeper in programme and portfolio level meetings rather than in the project level meetings. Thus, this value interaction needs a more dynamic and flexible mobilisation of resources, which may require not only a different project culture but also more project resources to execute this interaction.

\subsection{Phase 3: Refining and delivering value outcomes}

The evidence shows that refinements to the initial value propositions in the execution phase are required to successfully deliver a service. In this phase, we found two value interactions that may contribute to the delivery of value outcomes: (1) co-solving problems; and (2) co-transitioning from project to operations. These value interactions are explored in the following sections.

\subsubsection{Co-solving problems}

The evidence shows that problems in projects are inevitable and often arise during the project execution. Common grounding between the relevant stakeholders is required to secure and defend the delivery of value outcomes. To show a specific problem, in project case study 3 , the client organisation decided to carry out a refurbishment without the concern of the main stakeholders. The users and client representatives engaged until the project execution to discuss the service problems, such as an uninformed schedule of works during exams times and misconduct of the construction workers towards the end-users. The end-users decided to arrange a dialogue session with the client representatives to discuss and solve these and other problems. However, during the problem-solving sessions, one user stated:

The politeness from the institution was quite poor... we had one meeting with the manager to discuss the problems, the guy was responsible for the change, but we had that meeting, and nothing was nothing happening... he was so angry [with us] at that meeting"

(End-User - Case Study 3) 
During this problem-solving session, students were simply defending the (broken) promises about the conditions of their living experience. However, as evidence, the attitude from the client representative created more problems (most notably, a student strike), which derived in negative financial consequences to the client organisation. This demonstrates that stakeholders that are engaged in problem-solving situations required emotional intelligence skills to adequately manage these interactions, otherwise, it may result in a destruction of value as presented in project case study 3.

\subsubsection{Co-transitioning from project to operations}

The evidence suggests that the project need to be properly transferred from the project to the operations phase to secure the value outcomes. According to the data, project activities, such as service validation, system testing, and training may ensure that the value propositions shaped in the early stages are ultimately transferred to the operations. For example, in project case study 5, end-users who were helping to shape the value propositions in the early stages of the project, formed part of the acceptance testing activities as described below:

"We tested as went along with the system and at the end of that process we signed a user acceptance testing and we invited much of the end-users that we had in procurement and they came back and had a look at the system again with all the changes that we made"

(Senior Project Manager - Case Study 5)

The integration of the end-users at the front- and back-end of project created continuity and consistency across the project. In addition to this, in this case study, the project team co-developed the service with agility, meaning that mini-projects were developed and delivered in batches across the development sequence. This enabled the project team to test the new systems as going along across the development sequence. Overall, this value interaction may properly transfer value propositions from the conception to the project delivery.

\subsection{Phase 4: Managing and realising emergent value outcomes}

According to the evidence, once emergent value outcomes appear in the post-completion phase, they still need to be controlled and monitored so user stakeholders can effectively make use of them. For this phase, we found one value interaction that may ensure that value outcomes are managed during the service life.

\subsubsection{Co-managing value outcomes}


The data across the examined project studies suggest that client organisations often overlook managing the emergent value outcomes during the operations phase. For example, in project case study 2 , one participant stated:

"we don't have a dedicated manager doing contract management to make sure the SLA [service level agreements] are met and at the moment they are not"

(Head of IT Asset and Supplier Management - Case Study 2)

This suggests that disconnection between the project and operational level. Evidence demonstrating that clients do not invest in people, processes, and systems for managing contracts and their suppliers. This creates space for suppliers to behave unethically. For example, in the same project case study, the supplier was charging different prices as agreed in the initial contract. The client was not aware of this as no resources were allocated to oversee the contract. In addition to this, operational and service level agreement falls short of expectation as neither the supplier nor client manage to realise the envisioned value outcomes. In some occasion, the mismanagement of the value outcomes may lead to terminate the contract, as occurred in project case study 2. This resulted in overspending financial resources to the client organisation. Overall, data shows a lack of this value interaction across our case studies.

\subsection{Cross-tabulation of the co-creation themes vs. the case projects}

While a lot of results presented in the above sections may stem from a specific project case study, a crosstabulation of the eight value interactions is presented in this section to show the practices across the six cases studies. This cross-tabulation, which is represented in relative terms, shows that value interactions are not uniformly employed across all case studies. Four major observations from this cross-tabulation were found. Firstly, the more value interactions carried out by the client organisation, the better the value outcome was perceived by the end-users. For example, in project case study 4, value interactions were uniformly applied across this project and the overall value outcomes were perceived as successful by the end-users. This perception contrasts with other projects, such as case study 2 and 3 , where there was a lack of value interactions and outcomes were perceived as unsuccessful. Secondly, evidence across the cross-tabulation suggests that lack of value interactions in some projects produced negative financial implications. For example, in case study 3 , the client ended-up paying concessions which amounted to $£ 300,000$ in total due to the lack of the involvement with the main stakeholders during the initial stage of the project. This suggests that the creation of value outcomes is highly connected with the capture of value. 


\begin{tabular}{|c|c|c|c|c|c|}
\hline Item & Value Interactions & $\begin{array}{l}\text { Case Study 1: } \\
\text { Wi-Fi Service }\end{array}$ & $\begin{array}{l}\text { Case Study 2: } \\
\text { Printing Service }\end{array}$ & $\begin{array}{l}\text { Case Study 3: } \\
\text { Refurbishment }\end{array}$ & $\begin{array}{l}\text { Case Study 4: } \\
\text { Computing }\end{array}$ \\
\hline \multirow{3}{*}{ Phase 1} & $\begin{array}{l}\text { Co-learning with } \\
\text { internal and external } \\
\text { stakeholders }\end{array}$ & $\begin{array}{l}\text { Moderately; the } \\
\text { client learned from } \\
\text { other clients in the } \\
\text { same sector. }\end{array}$ & $\begin{array}{l}\text { Null; the client did not } \\
\text { manage to learn from } \\
\text { existing and similar } \\
\text { client settings. }\end{array}$ & $\begin{array}{l}\text { Null; the client did } \\
\text { not learn from other } \\
\text { clients, probably } \\
\text { due to the low } \\
\text { complexity } \\
\text { presented in this } \\
\text { project. }\end{array}$ & $\begin{array}{l}\text { Strongly; the } \\
\text { client learned } \\
\text { from other client } \\
\text { Invited another } \\
\text { client to join } \\
\text { procurement } \\
\text { sessions. }\end{array}$ \\
\hline & $\begin{array}{l}\text { Co-revealing existing } \\
\text { service systems }\end{array}$ & $\begin{array}{l}\text { Strongly; the client } \\
\text { directly explored } \\
\text { existing supplier's } \\
\text { service system. }\end{array}$ & $\begin{array}{l}\text { Null; the client did not } \\
\text { manage to explore } \\
\text { other existing and } \\
\text { similar settings. }\end{array}$ & $\begin{array}{l}\text { Null; this project } \\
\text { was a unique } \\
\text { service, this type of } \\
\text { interaction was not } \\
\text { required. }\end{array}$ & $\begin{array}{l}\text { Strongly; the } \\
\text { client explored } \\
\text { the supplier's } \\
\text { system in other } \\
\text { similar settings. }\end{array}$ \\
\hline & $\begin{array}{l}\text { Co-aligning strategic } \\
\text { needs and } \\
\text { expectations }\end{array}$ & $\begin{array}{l}\text { Moderately; the } \\
\text { client only engaged } \\
\text { with the supplier but } \\
\text { not with users to } \\
\text { understand the } \\
\text { needs and } \\
\text { expectations. }\end{array}$ & $\begin{array}{l}\text { Moderately; the client } \\
\text { only engaged with } \\
\text { the supplier but not } \\
\text { with users to } \\
\text { understand the } \\
\text { needs and } \\
\text { expectations. }\end{array}$ & $\begin{array}{l}\text { Null; the client did } \\
\text { not carry out any } \\
\text { sort of early } \\
\text { engagement with } \\
\text { supplier and fully } \\
\text { ignored end-users. }\end{array}$ & $\begin{array}{l}\text { Strongly; the } \\
\text { client fully } \\
\text { engaged with the } \\
\text { supplier and } \\
\text { users. }\end{array}$ \\
\hline \multirow{2}{*}{ Phase 2} & $\begin{array}{l}\text { Co-designing for } \\
\text { service experience }\end{array}$ & $\begin{array}{l}\text { Moderately; the } \\
\text { client and supplier } \\
\text { used design tools to } \\
\text { synchronise different } \\
\text { channels of } \\
\text { communication. }\end{array}$ & $\begin{array}{l}\text { Null; but the client } \\
\text { recognised this type } \\
\text { of interaction was } \\
\text { required, as the } \\
\text { operations team } \\
\text { ended-up designing } \\
\text { the service. }\end{array}$ & $\begin{array}{l}\text { Null; the client did } \\
\text { not apply this type } \\
\text { of interaction. }\end{array}$ & $\begin{array}{l}\text { Moderately; the } \\
\text { client and suppli } \\
\text { carried out } \\
\text { engagements } \\
\text { sessions to } \\
\text { design the user } \\
\text { experience with } \\
\text { the end-users. }\end{array}$ \\
\hline & $\begin{array}{l}\text { Co-developing a } \\
\text { service with agility }\end{array}$ & $\begin{array}{l}\text { Moderately; the } \\
\text { client and supplier } \\
\text { worked on closely } \\
\text { on, not in developing } \\
\text { a system, but in the } \\
\text { delivery. }\end{array}$ & $\begin{array}{l}\text { Weakly; the contract } \\
\text { was co-developed, } \\
\text { but it was it did not } \\
\text { meet the client's } \\
\text { needs. }\end{array}$ & $\begin{array}{l}\text { Null; but the client } \\
\text { could have clearly } \\
\text { co-developed } \\
\text { protocols of } \\
\text { communications. }\end{array}$ & $\begin{array}{l}\text { Weakly; only in } \\
\text { the delivery, as } \\
\text { the IT system wa } \\
\text { already fully } \\
\text { developed by the } \\
\text { supplier. }\end{array}$ \\
\hline \multirow[b]{2}{*}{ Phase 3} & Co-solving problems & $\begin{array}{l}\text { Moderately; the } \\
\text { client work } \\
\text { alongside the } \\
\text { supplier and users. }\end{array}$ & $\begin{array}{l}\text { Weakly; lack of } \\
\text { engagement from the } \\
\text { supplier to solve } \\
\text { issues. }\end{array}$ & $\begin{array}{l}\text { Null; the client reps } \\
\text { engaged with users } \\
\text { but, an ineffective } \\
\text { client dialogue } \\
\text { management worse } \\
\text { the problem. }\end{array}$ & $\begin{array}{l}\text { Strongly; the } \\
\text { client, supplier } \\
\text { and users worke } \\
\text { together in the } \\
\text { execution at } \\
\text { project/board } \\
\text { level. }\end{array}$ \\
\hline & $\begin{array}{l}\text { Co-transitioning } \\
\text { from project to } \\
\text { operations }\end{array}$ & $\begin{array}{l}\text { Weakly; the client } \\
\text { lost the relationship } \\
\text { with the supplier at } \\
\text { this stage. }\end{array}$ & $\begin{array}{l}\text { Weakly; the client } \\
\text { lost the relationship } \\
\text { with the supplier at } \\
\text { this stage. }\end{array}$ & $\begin{array}{l}\text { Weakly; the client } \\
\text { lost the relationship } \\
\text { with the supplier at } \\
\text { this stage. }\end{array}$ & $\begin{array}{l}\text { Moderately; the } \\
\text { transition was } \\
\text { carried in one } \\
\text { single phase frol } \\
\text { the project level } \\
\text { to operations. }\end{array}$ \\
\hline Phase 4 & $\begin{array}{l}\text { Co-managing value } \\
\text { outcomes }\end{array}$ & $\begin{array}{l}\text { Weakly; service } \\
\text { review interactions } \\
\text { in place but without } \\
\text { improvements in the } \\
\text { service. }\end{array}$ & $\begin{array}{l}\text { Weakly; a few } \\
\text { service review } \\
\text { interactions and } \\
\text { improvements across } \\
\text { the contract, except } \\
\text { when the contract } \\
\text { was being } \\
\text { terminated. }\end{array}$ & $\begin{array}{l}\text { Null; the client } \\
\text { manages its own } \\
\text { building facilities so } \\
\text { no interactions was } \\
\text { carried out. }\end{array}$ & $\begin{array}{l}\text { Strongly; service } \\
\text { review } \\
\text { interactions in } \\
\text { place with servic } \\
\text { improvements. }\end{array}$ \\
\hline
\end{tabular}




\begin{tabular}{|c|c|c|c|c|}
\hline $\begin{array}{l}\text { Perception of the } \\
\text { value outcomes } \\
\text { (perceived by the } \\
\text { interviewees) }\end{array}$ & $\begin{array}{l}\text { Relatively } \\
\text { Unsuccessful: the } \\
\text { client considered } \\
\text { this project as } \\
\text { successful due to a } \\
\text { cheap contract, } \\
\text { however, users } \\
\text { experienced poor } \\
\text { operational and } \\
\text { experiential } \\
\text { outcomes. }\end{array}$ & $\begin{array}{l}\text { Unsuccessful: the } \\
\text { client perceived } \\
\text { operational and } \\
\text { financial outcomes as } \\
\text { unsatisfactory. Thus, } \\
\text { contract was } \\
\text { terminated. }\end{array}$ & $\begin{array}{l}\text { Unsuccessful: the } \\
\text { client and users } \\
\text { experienced poor } \\
\text { experiential, } \\
\text { financial and social } \\
\text { outcomes. Users, in } \\
\text { particular, felt } \\
\text { mistreated during } \\
\text { the project } \\
\text { execution. }\end{array}$ & $\begin{array}{l}\text { Successful: } \\
\text { Operational } \\
\text { outcomes are w } \\
\text { regarded by the } \\
\text { users, with a } \\
\text { good capacity fc } \\
\text { future demands. }\end{array}$ \\
\hline
\end{tabular}

Note: This table is a cross-tabulation of the co-creation themes vs. the case projects from the client perspective (how strongly in relative terms).

Table 5. Cross-tabulation of the co-creation themes vs. the case projects 
Thirdly, the cross-tabulation shows that while some projects may have carried out value interactions during the early stages of a project (see case study 1), this does not ensure that value outcomes are realised during the operations phase. This suggests that when required value interactions need to be uniformly applied across the project development sequence to ensure value outcomes are transferred from the front- to back-end of a project. Finally, the cross-tabulation shows that not all the projects have to carry out the eight value interactions in each project. Value interactions are mainly triggered by elements of uncertainty and complexity present in a project. For example, in case study 5 , there were no other existing solutions that the client project team could learn from, so this type of value interaction was not required. Overall, the eight value interactions may be considered as a mini-portfolio of management actions, which may lead to ensure value outcomes in the longterm.

\section{Discussion}

The goal of this research was to identify and explore value interactions that may impact the client's value outcomes in the medium- and long-term. To discuss this, the section is divided into two main parts according to the research questions: (1) a discussion of the value interactions that may enhance value outcomes; 2) a discussion of the implications of the value interactions in medium- and long-term. To facilitate the discussion, Figure 1 has been developed to show the connections between the different value interactions across the development of value outcomes and the types of value outcomes that appear in the long-term.

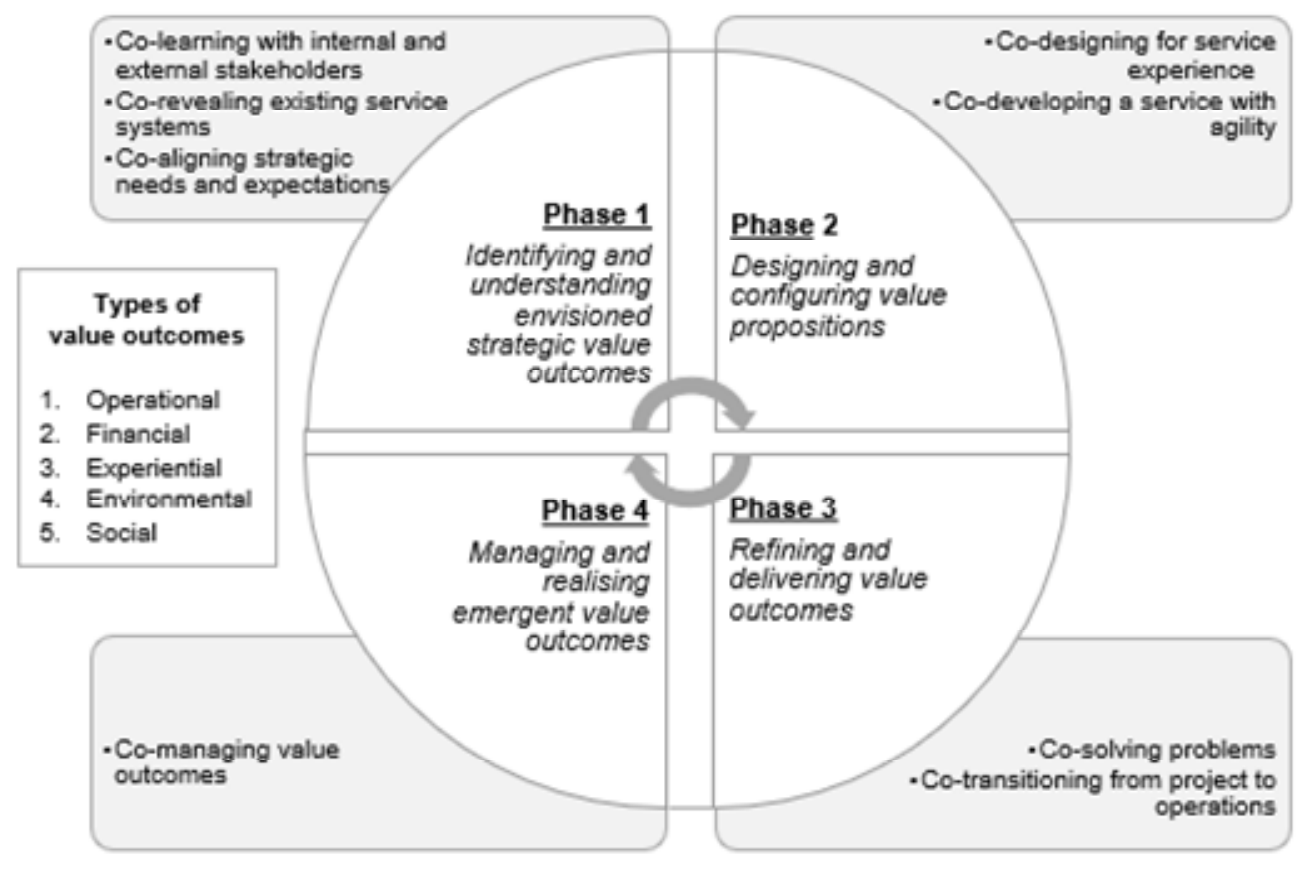


Figure 1. Process of the co-creation of value outcomes in project settings (Authors' own).

\subsection{Value interactions across project stages}

The results identified eight specific value interactions (see Figure 1), which may enhance the value outcomes in the medium- and long-term. The eight interactions can be seen as an alternative perspective to overcome uncertainty and complexity challenges in projects. For example, in project case study 4, the client had uncertainty in the technical system design. Thus, the client carried out a co-learning interaction with an external actor, who had previously undertaken a similar project to overcome the uncertainty and enhance at the same time the value outcome. This functionality of value co-creation, particularly to overcome complex situations, is in line with previous research findings from industrial solutions studies (cf. Luotola et al. 2017).

One originality of this study is to have identified and explored value interactions from the ground. This is due to the fact that previous studies in project management and marketing have not comprehensively specified value interactions in the micro-level or have provided evidence-based challenges to the concept of value cocreation (cf. Vargo and Lusch 2004; Prahalad and Ramaswamy 2004; Smyth and Pryke 2008). For example, the usefulness of the co-learning interaction has been explored in project settings (cf. Davies and Hobday 2005; Chesbrough 2011; Davies et al. 2016). However, our exploration in the micro-level suggests that full empowerment to external actors in a co-learning process may be counterproductive. In particular, in project case study 4, client representatives had to stop the learning interaction to secure the value outcomes as the external stakeholder was not aware of the client's organisational context. This could have led to destructive management decisions for the client instead. This finding contrasts with Karpen et al. (2011), who theoretically suggest to fully empower stakeholders in the co-creation process. In a similar manner, the co-solving problems interaction has been previously explored in project settings (cf. Pryke 2017), but our evidence suggests that stakeholders need to hold emotional intelligence skills to manage problematic interactions, otherwise they may destroy value. For example, in project case study 3, the lack of emotional intelligence skills from the client representatives derived in a confrontation with the students, who decided to organise themselves and defend their value outcomes through strike action.

As an original contribution, this study found that the interaction: co-revealing existing service systems, allows one organisation to explore tangible and intangible aspects of an existing service system from an early stage 
of a project. For example, in project case study 1, the client was able to perceive the supplier organisational culture by observing existing processes, operations and service actors. While this value interaction may be less useful for unique projects such as in construction undertakings, IT projects, which are based on repeatable hardware solutions (see Davies and Hobday 2005), can reap benefits out of this interaction as service systems can be examined from an early stage.

Some other value interactions found in this study, they form part of the new wave of adaptive project management. For example, in the interaction co-developing for service with agility, particularly in project case study 5 , the project team used a flexible approach to develop a project. The team carried out multiple replanning interactions to modify initial requirements according to the evolving needs. This contrasts with the traditional rigid planning, where projects freeze the initial planning stage (Serrador and Pinto 2015). However, the evidence suggests that a new culture and investment in the form of new processes, systems, and training, is needed to carry out this interaction iterative interaction. In addition to this interaction, this study found that the interaction co-designing for service experience is scarcely applied in project practice. The analysis suggests that when project teams do not co-design service experiences, it may result in negative financial consequences. For example, in project case study 3 , the project team did not engage with the users to codesign the service experience. This resulted in $£ 300,000$ of compensations to users as users complained about the functionality of the service. To bridge theory with practice, service design tools may be well used to address this interaction, such as the blueprinting technique (Shostack 1984), user design (Redström 2006), customer journey (Zomerdijk and Voss 2010) and multi-level design (Patrício et al. 2011; Teixeira et al. 2012)..

Other value interactions have been previously explored in projects, such as co-aligning needs and expectations (cf. Brady et al. 2005; Morris, 2013), co-transitioning projects to operations (cf. Zerjav et al. 2015; Zerjav et al. 2018) and co-managing value outcomes (cf. Cova et al. 2002). Thus, this study confirms that while the strategic front-end is critical to configure value outcomes (Morris 2013), projects needs to expand their scope beyond the transaction and short-term perspectives in order to connect effectively the front- with the back-end of a project (Artto et al. 2016).

In summary, the first research question has been covered in this section. We found eight specific value interactions across the project lifecycle, which may not only enhance the value outcomes in the long-term but also can help to deal with uncertain and complex situations. Overall, this list is not meant to be an inclusive 
list, but it may provide initial exposure of current co-creation practices. However, one can argue that these interactions might not be relevant to all markets or projects, particularly as the interactions have been identified from a public sector organisation.

\subsection{Implications of the value interactions in medium- and long-term.}

While the evidence demonstrates project actors endorse and focus on short-term value outcomes, particularly financially, value interactions may definitely have either positive or negative implications in the medium- and long-term. For example, according to our analysis (see Figure 1), the (lack of) application of value interactions across the project life-cycle resulted in five different types of value outcomes in the longterm: (1) Operational; (2) Financial; (3) Experiential; (4) Environmental and (5) Social. This integrated and connected set of value outcomes, produced by value interactions, is an original contribution to the literature of projects. This is due to the fact that the literature in benefits management has considered benefits as a measurement of the delivery of tangible outputs (cf. Morris 2013). Yet, the value realisation of the tangible and intangible aspects in a project have been overlooked. In addition to this, benefits have been considered a homogenous mass as if all benefits had the same properties and characteristics. In contrast, our analysis shows five dimensions of strategic value outcomes. This categorisation could be potentially used in the strategic business case for initial exploration of value outcomes. According to our analysis of the project business case, the allocation of value outcomes is loose at the early of a project, but they need to be strategically agreed and tied up. For example, in project case study 1 , the benefits section in the business case was completely overlooked. This suggests that client organisations may pursue agendas, which may compromise the value outcomes for the end-users or other relevant stakeholders.

These set of value outcomes resemble previous individual exploration of value outcomes. For example, social and environmental outcomes have been previously discussed in Martinsuo and Killen (2014); operational outcomes in Zerjav et al. (2018); financial outcomes in Smyth et al. (2017); and experiential outcomes in Fuentes (2018). Another originality in this study is to show how these value outcomes could be interconnected. For example, in project case study 3, the client did not co-design the service experience with the end-users, which ultimately affected the financial outcomes upstream to the client organisation and the experiential outcomes downstream to the end-users during the execution phase of a project. In addition to this, using the 
service perspective from Vargo and Lusch (2016), value outcomes can emerge both during the execution phase (as in project case study 3) and during the operations phase.

Another originality is to empirically show that although value outcomes emerge in the medium- and long-term, value outcomes have a link back to the early project stage. To manage the value outcomes from the early stages, this study has identified a process comprised of four phases (see Figure 1), by which value outcomes can be managed. Traditional project life cycles rely upon new product development sequence (NPD), particularly in construction projects (see Morris 2013). In contrast to the rigid NPD approaches, the four phases to manage value outcomes allow the identification, design, and refinement of value outcomes in a project. These four phases are in line with modern adaptive project management (Levitt 2011; Serrador and Pinto 2015).

In summary, the second research question has been covered in this section. We explored the extent by which value interactions have an impact in the long-term. The results show that the value interactions may produce a set of value outcomes, which may appear in the medium and long-term. In addition to this, our analysis demonstrates that while the value outcomes appear in the long-term, they have a link back to the early stage of a project. Thus, four phases have been identified to manage the value outcome across the project life cycle. These phases are in line with modern adaptive project management approaches.

\section{Conclusion and Implications}

To date, research on the strategic pre-project stage has ensured a better definition of projects (Morris 2013). However, research on the value outcomes in the medium- and long-term has been scarcely addressed in the project literature. In addition to this, previous studies on value have been emphasised from the supplier point of view (see Davies 2004). The management and the perception of value outcomes from the client perspective have been widely disregarded. Thus, the overarching originality of this study comes from the examination of Service Dominant-Logic in the project context, which aims to ensure value outcomes for the client business in the medium- and long-term through value interactions as management actions. 


\subsection{Theoretical contribution}

This research contributes to knowledge in three main streams:

Firstly, this research empirically identified eight specific value interactions (see Figure 1), which may be used as management actions not only to enhance value outcomes in the long-term but also to deal with complex and uncertain situations at present. Previous research in projects such as relationship marketing has addressed collaborative relationships but specific value interactions have not been sufficiently specified at the micro level, as this study does (cf. Vargo and Lusch 2004; Prahalad and Ramaswamy 2004; Smyth and Pryke 2008).

While these eight interactions may create value in the long-term, one can argue that, for known situations, independent and transactional management is enough, particularly when the expertise has been reached by the experiences of previous projects. This contrasts with the proposition from Vargo and Lusch (2016) who argue that a value co-creation process must take across the entire project lifecycle. However, our results show that a collaborative process might become counterproductive or destructive for project settings (cf. Mills and Razmdoost (2016), for example in overspending of resources (cf. Hamel and Prahalad 1994); in creating conflicts or scope creep (cf. Mele 2011); or in adding complexity to the project. In addition to this, results show practitioners may need to stop and disallow the external co-creator in order to defend the outcomes. This finding is in contrast to Karpen et al. (2011), who theoretically suggest to fully empower stakeholders in the co-creation process.

Secondly, this research empirically created a categorisation of five different types of value outcomes, from a client perspective, which appears in the medium and long-term. This set of tangible and intangible value outcomes contrasts previous work on benefits management (see Chih and Zwikael 2015), which considered benefits as a homogenous entity. Furthermore, while previous project research has explored some forms of value outcomes (Morgan et al. 2007; Martinsuo and Killen 2014; Zerjav et al. 2018; Smyth et al. 2017; Fuentes 2018), this study shows the how these set of value outcomes might be interconnected, rather than being treated as isolated entities. In addition to this, previous research on projects considered that outcomes appear in the long-term (Shenhar and Dvir 2007). However, this research empirically demonstrated that execution embodies service interactions and is part of the service experience, hence conceptually value outcomes are also experienced during execution (cf. Smyth, 2015). 
Thirdly, this research found that allocation of the value outcomes is highly affected by power asymmetry among the relevant actors in the co-creation process, which, in turn, may result in negative consequences for another party, for example, the client pursuing its agendas compromised the outcomes for other stakeholders. This contribution may be linked with previous stakeholder management findings (see Mitchell et al. 1997), which argue that actors with specific attributes, such as power, urgency, and legitimacy, may have a strong influence in a collaborative relationship. In addition to this, our results indicate that unethical behaviour between projects actors is quite common, particularly as suppliers are financially driven organisations. For example, in project case study 2, the supplier took advantage that the client was not properly managing the supplier during the contract management and were charging different prices as agreed in the initial contract. This finding contrasts the theoretical propositions from Akaka et al. (2013), who highly advocates that the whole actors ecosystem are willing to collaborate for the benefit of the client and end-users.

Overall, this research adds to existing knowledge by continuing to unpack the process and implications of the co-creation of value outcomes. This research is original because it has moved forward the concept of the cocreation of value. Previous research on co-creation has been criticised for being normative and perspective (Wright Russell 2012) and rooted in positive terms (Mele 2011). In contrast, this research provides eight value interactions which may be considered as key management actions to enhance benefits. In addition to this, several challenges have been brought forward to the concept and adequacy of value co-creation in projects. These challenges which may require management attention to ensure and defend the value outcomes from a client perspective.

\subsection{Managerial implications and recommendations}

This study has identified four main implications and recommendations for project practitioners, Firstly, the identification of the eight value interactions (see Figure 1) might serve as specific management actions for project practitioners, by which benefits, and value outcomes are initially identified, designed, delivered and managed across the development sequence, particularly when complexity and uncertainty aspects are at stake. From a practical point of view, if any of the proposed interactions are carried out, we recommend practitioners to scope the co-creation task to clearly identify what needs to be co-created. Secondly, while value co-creation process may create benefits, practitioners to understand when to avoid or to stop a cocreation process, as the value interactions may result in counterproductive and destructive practices, reflected as conflicts or overspending of resources. Thus, project practitioners need to discuss the advantages and disadvantages of a co-creation process. Thirdly, from our analysis of the six project business cases, value 
outcomes (usually referred as to benefits) are poorly treated at the planning stage. Thus, the categorisation of the five types of value outcomes (see Figure 1) might help practitioners in the initial development of business cases. From a practical point of view, we recommend practitioners to make use of workshops to discuss strategic value outcomes for the long-term, which could later inform the project specification. Lastly, moving into a management of value outcomes is not a straightforward process. This requires investment in terms of creating new processes, activities, resources, and personnel training as modern forms of management are required. However, according to our analysis, this investment may help in avoiding negative implications vis a vis their business models in the long-term.

\subsection{Limitations and directions for further research}

Two main limitations have been identified in this study. Firstly, the limited empirical studies on co-creation in project settings led the researchers to select a focal firm context to understand the phenomena within the same contextual contingencies. While this allowed us to understand in-depth the organisational context, the history of the projects, and the value outcomes in the long-term from one specific organisation, this might indicate that some findings might not be relevant or applicable to other organisations and project markets. However, that was not the specific research goal, as our employed research methodology: critical realism, is not focused per in seeking generalisable results, but instead in developing causal explanations. Secondly, while the number of interviews is substantial, the main perception of the value outcomes is coming from the client rather than from the supplier organisation. Thus, this might have created a bias in the analysis of the value outcomes.

This research has found five main avenues for future research:

(1) process and techniques could be developed to identify and categorise different types and roles of cocreators. A complex project with multiple actors in the co-creation process could be helpful to map the different roles of co-creators. This may also provide an indication of the type of skills and knowledge required for this collaborative process (see Mitchell et al 1997; Aaltonen et al. 2016).

(2) the number of tensions found in this study might indicate that co-creation practices in the micro-level have not yet been explicitly explored (see Storbacka et al. 2016). Thus, further exploration of the micro levels aspects of co-creation of value is required across the portfolio, programme and project level both from the client and supplier perspective.

(3) contextual factors seem to influence the co-creation process, from the institutional to the project level, thus a full exploration of the context around the process of co-creation is required (Edvardsson 2011). 
(4) service design practices need to be further explored to understand how projects practitioners are designing service experiences. At present, designing for service experiences have been scantly explored in practice and theory. Thus, there is a clear route of action research in project settings (see Shostack 1984; Redström 2006; Zomerdijk and Voss 2010; Patrício et al. 2011; Teixeira et al. 2012).

(5) To date, research on co-creation is in isolation with wider organisational aspects such as the business model and strategy (cf. DaSilva and Trkman 2014). This research uncovered links and signals the need for further integrative research across the management research silos.

Conflict of interest There is no conflict of interest.

Acknowledgments We would like to thank reviewers for their insightful comments on this special issue, as their comments led us to an improvement of the work and directly contributed to the PhD thesis of the first author. We would like to thank our colleagues at Åbo Akademi University in Finland, particularly Prof. Kim Wikström and Dr. Magnus Gustafsson, for hosting the first author during his PhD analysis period. In addition to this, we express our gratitude to the Mexican National Council of Science and Technology (CONACYT) for funding this research. 


\section{1st order of synthesis}

Learning from other projects and actors to solve technical, commercial and other service wrap

Through the dialogue meetings, clients are able to refine and share other resources, such as project documentation, to absorb lessons learned Learning from the experience of others and applying lessons learnt to the benefit of the client

Ethical engagement to provide valuable sources of information

Win-win situations for parties engaged in the co-creation, yet power may influence the interaction

Observing the physical environment, operations and other routines during real-time service delivery settings

Corroborating project documentation with existing operations, systems and processes

Interacting with employees and existing processes to understand their organisational context, such as culture and the employees' service ability.

Early discussion of contracts and projects in the form of market engagements, supplier briefings and consultations. Commercial awareness was needed during these discussions.

Late design in the process during the actual execution and operations phase

Lack of engagement with roles from the operations phase with the frontend

Lack of tools and processes to map and backcast the value outcomes

Investment is required to change the process and culture

Changes in the dynamics of the people within the organisation

Changes in the system could cause problems for the established routines

Iterations across the development sequence

Use of development and sprint sessions to re-plan and deliver

Culture change in the way of working

Consuming more resources than planned and in comparison to other projects

Financial rewards when applying co-development

Changes in the plan and project scope need to be agreed with different project actors

A process in place to keep control of the changes and problems

Challenging situations need to be properly addressed by relevant stakeholders

The transition from projects to operation is not planned by the PMO

Project resources limited to the project lifecycle

Systems not connected with the overall service system

Disconnection of the relationship during the contract lifecycle

Clients need to allocate resources to keep control of the suppliers 2nd order of synthesis

Absorbing explicit

knowledge

Absorbing implicit

knowledge

Interaction awareness

due to contextual factors

Understanding tangible aspects of the service system

Understanding intangible aspects of the service system

Exploring needs and expectations from relevant actors

Engagement with actors in execution and operations

Investment to carry out this interaction through formal processes

Changes in the routines

Flexibility in the process

Development of organisational attributes Dynamics in the financial resources

Processes to track and solve problems

Soft skills to address and solve problem

Formal process to transfer projects to operations

Allocation of project resources to the operations

Synchronisation of systems in the operations Formal contract management procedures
Aggregated synth Value interactions

Co-learning with int and external stakel

Co-revealing the ex service system

Co-aligning strateg and expectations

Co-designing for se experience

Co-developing a se with agility

Co-solving problem

Co-transitioning fro project to operation

Co-managing value outcomes 
Appendix 1. Synthesis of the CR results. 


\section{References}

Aaltonen, K., Kujala, J., Havela, L. and Savage, G., 2015. Stakeholder Dynamics During the Project FrontEnd: The Case of Nuclear Waste Repository Projects. Project Management Journal, 46(6), pp.15-41.

Aarikka-Stenroos, L. and Jaakkola, E., 2012. Value co-creation in knowledge intensive business services: A dyadic perspective on the joint problem solving process. Industrial marketing management, 41(1), pp.15-26.

Akaka, M.A., Vargo, S.L. and Lusch, R.F., 2013. The complexity of context: A service ecosystems approach for international marketing. Journal of Marketing Research, 21(4), pp.1-20.

Artto, K., Ahola, T. Vartiainen, V., 2016. From the front end of projects to the back end of operations: Managing projects for value creation throughout the system lifecycle. International Journal of Project Management, 34(2), pp.258-270.

Ballantyne, D. and Varey, R.J., 2006. Introducing a dialogical orientation to the service-dominant logic of marketing. The service-dominant logic of marketing: Dialog, debate, and directions, pp.224-35.

Barney, J., 1991. Firm resources and sustained competitive advantage. Journal of management, 17(1), pp.99-120.

Bettencourt, L A, Lusch, R F and Vargo, S L, 2014. A service lens on value creation.

California Management Review, 57(1), 44-66.

Bhaskar, R., 2008. A Realist Theory of Science. London: Routledge.

Brady, T., Davies, A. and Gann, D.M., 2005. Creating value by delivering integrated solutions. International Journal of Project Management, 23(5), pp.360-365.

Chang, A., Chih, Y.Y., Chew, E. and Pisarski, A., 2013. Reconceptualising mega project success in Australian Defence: Recognising the importance of value co-creation. International Journal of Project Management, 31(8), pp.1139-1153.

Chesbrough, H.W., 2011. Bringing open innovation to services. MIT Sloan Management Review, 52(2), p.85.

Chih, Y.Y., Zwikael, O., 2015. Project benefit management: A conceptual framework of target benefit formulation. International Journal of Project Management, 33(2), pp.352-362.

Cova, B., Ghauri, P. \& Salle R., 2002. Project Marketing: Beyond Competitive Bidding. Chichester: Wiley \& Sons.

Cova, B., Salle, R., 2008. Marketing solutions in accordance with the SD logic: Co-creating value with customer network actors. Industrial marketing management, 37(3), pp.270-277.

Danermark B, Ekstrom M, Jakobsen L, Karlsson J., 2002. Explaining society: critical realism in the social sciences. Routledge, London.

Davies, A., 2004. Moving base into high-value integrated solutions: a value stream approach. Industrial and Corporate Change, 13(5), pp.727-756.

Davies, A. and Hobday, M., 2005. The business of projects: managing innovation in complex products and systems. Cambridge: Cambridge University Press. 
Davies, A., Dodgson, M., and Gann, D. M. 2016. Dynamic capabilities for a complex project: The case of London Heathrow Terminal 5. Project Management Journal, Special Issue: Innovation and Project Management: Bridging Contemporary Trends in Theory and Practice, 47(2), pp.26-46.

DaSilva, C.M. and Trkman, P., 2014. Business model: What it is and what it is not. Long range planning, 47(6), pp.379-389.

Denzin, N.K. and Lincoln, Y.S., 2000. Handbook of qualitative research. $2^{\text {nd }}$ Edition. Thousand Oaks: Sage. Echeverri, P. and Skålén, P., 2011. Co-creation and co-destruction: A practice-theory based study of interactive value formation. Marketing theory, 11(3), pp.351-373.

Edkins, A., Geraldi, J., Morris, P., Smith, A., 2013. Exploring the front-end of project management. Engineering Project Organization Journal, 3(2), pp.71-85.

Edvardsson, B., Tronvoll, B., and Gruber, T. 2011. Expanding understanding of service exchange and value co-creation: a social construction approach. Journal of the Academy of Marketing Science, 39(2), 327-339.

Eisenhardt, K.M. and Graebner, M.E., 2007. Theory building from cases: Opportunities and challenges. Academy of management journal, 50(1), pp.25-32.

Emerson, R. M., Fretz, R. I., \& Shaw, L. L. (2001). Participant observation and fieldnotes. In P. Atkinson, A. Coffey, S. Delamont, J. Lofland \& L. Lofland (Eds.), Handbook of ethnography (pp. 352-368). London: Sage.

Engwall, M., 2003. No project is an island: linking projects to history and context. Research policy, 32(5), pp.789-808.

Fuentes, M., and Smyth, H., 2016. Value co-creation in a project setting: A Service-Dominant Logic Perspective. Paper presented at the Annual ARCOM Conference, Manchester, UK. 2016

Fuentes, M., 2019. Co-creation and co-destruction of experiential value: a service perspective. Built Environment Project and Asset Management. Special Issue: Service innovation through linking design, construction and asset management.

Foss, N.J. and Pedersen, T., 2016. Microfoundations in strategy research. Strategic Management Journal, 37(13), pp.E22-E34.

Gioia, D.A., Corley, K.G. and Hamilton, A.L., 2013. Seeking qualitative rigor in inductive research: Notes on the Gioia methodology. Organizational research methods, 16(1), pp.15-31.

Grönroos, C., 1984. A service quality model and its marketing implications. European Journal of marketing, 18(4), pp.36-44.

Grönroos, C., 2011. Value co-creation in service logic: A critical analysis. Marketing theory, 11(3), pp.279301.

Grönroos, C. and Voima, P., 2013. Critical service logic: making sense of value creation and cocreation. Journal of the academy of marketing science, 41(2), pp.133-150.

Grönroos, C. and Gummerus, J., 2014. The service revolution and its marketing implications: service logic vs service-dominant logic. Managing service quality, 24(3), pp.206-229.

Grönroos, C., 2017. On Value and Value Creation in Service: A Management Perspective. Journal of Creating Value, 3(2), pp.125-141.

Hamel, G. and Prahalad, C.K., 1994. Competing for the future. Harvard business review, 72(4), pp.122-128.

Hellström, M., Wikström, R., Gustafsson, M. and Luotola, H., 2016. The value of project execution services: a problem and uncertainty perspective. Construction Management and Economics, 34(4-5), pp.272-285. 
Huemann, M. and Zuchi, D., 2014. Toward a comprehensive project stakeholder management approach for HR projects. In R. Klimoski, B. Dugan, C. Messikomer, \& F. Chiocchio (Eds.), Advancing human resource project management, pp. 383-424. San Francisco, CA: Jossey-Bass

Isaksen, K., 2016. Reclaiming rational theory choice as central: a critique of methodological applications of critical realism. Journal of critical realism, 15(3), pp.245-262.

Jaakkola, E. and Hakanen, T., 2013. Value co-creation in solution networks. Industrial Marketing Management, 42(1), pp.47-58.

Jacobsson, M. and Roth, P., 2014. Towards a shift in mindset: partnering projects as engagement platforms. Construction Management and Economics, 32(5), pp.419-432.

Karpen, I. O., Bove, L. L., Lukas, B. A., 2011. Linking service-dominant logic and strategic business practice: A conceptual model of a service-dominant orientation. Journal of Service Research: 15(1), pp. 21-38.

Kim, J. and Wilemon, D., 2002. Focusing the fuzzy front-end in new product development. R\&D Management, 32(4), pp.269-279.

Kujala, S., Kujala, J., Turkulainen, V., Artto, K., Aaltonen, P. and Wikström, K., 2011. Factors influencing the choice of solution-specific business models. International Journal of Project Management, 29(8), pp.960970.

Konstantinou, E. and Müller, R., 2016. The role of philosophy in project management. Project Management Journal, 47 (2016) 3: 3-11

Laursen, M. and Svejvig, P., 2016. Taking stock of project value creation: A structured literature review with future directions for research and practice. International Journal of Project Management, 34(4), pp.736-747.

Leiringer, R and Bröchner, J. 2010. Service-led construction projects. Construction Management and Economics. 28 (11), pp.1123-1129.

Lepak, D.P., Smith, K.G. and Taylor, M.S., 2007. Value creation and value capture: a multilevel perspective. Academy of management review, 32(1), pp.180-194.

Leroy, J., Cova, B. and Salle, R., 2013. Zooming in VS zooming out on value co-creation: consequences for BtoB research. Industrial Marketing Management, 42(7), pp.1102-1111.

Levitt, R.E., 2011. Towards project management 2.0. Engineering Project Organization Journal, 1(3), pp.197-210

Lincoln, Y.S. and Guba, E.G., 1985. Establishing trustworthiness. Naturalistic inquiry, 289, p.331.

Liu, A. M. M., Fellows, R., Chan, I. Y. S, 2014. Fostering Value Co-creation in Construction: A Case Study of an Airport Project in India. International Journal of Architecture, Engineering and Construction, 3(2): pp.120-130.

Luotola, H., Hellström, M., Gustafsson, M., Perminova-Harikoski, O., 2017. Embracing uncertainty in valuebased selling by means of design thinking. Industrial Marketing Management. 65, pp.59-75

Lusch, R. F., \& Vargo, S. L. (2014). The service-dominant logic of marketing: Dialog, debate, and directions. New York: Routledge.

Martinsuo, M. and Killen, C.P., 2014. Value management in project portfolios: Identifying and assessing strategic value. Project Management Journal, 45(5), pp.56-70.

Matinheikki, J., Artto, K., Peltokorpi, A. and Rajala, R., 2016. Managing inter-organizational networks for value creation in the front-end of projects. International journal of project management, 34(7), pp.12261241. 
Mele, C., 2011. Conflicts and value co-creation in project networks. Industrial Marketing Management, 40(8), pp.1377-1385.

Mills, G.R., Razmdoost, K., 2016. Managing value co-creation/destruction: a longitudinal education capital programme/project case study. Construction Management and Economics, 34(4-5), pp.286-301.

Mitchell, R. K., Agle, B. R., \& Wood, D. J. (1997). Toward a theory of stakeholder identification and salience: Defining the principle of who and what really counts. Academy of management review, 22(4), 853-886.

Morgan, M., Malek, W.A. and Levitt, R.E. 2008. Executing your strategy: How to break it down and get it done. Boston, MA: Harvard Business School Press.

Morris, P.W., 2013. Reconstructing project management. Chichester, UK: John Wiley \& Sons.

Normann, R. and Ramirez, R., 1993. From value chain to value constellation: Designing interactive strategy. Harvard business review, 71(4), pp.65-77.

Papke-Shields, K.E., Beise, C. and Quan, J., 2010. Do project managers practice what they preach, and does it matter to project success?. International journal of project management, 28(7), pp.650-662.

Patrício, L, Fisk, R P and Constantine, L., 2011. Multilevel service design: from customer value constellation to service experience blueprinting. Journal of Service Research. 14 (2), pp.180-200.

Payne, A.F., Storbacka, K. and Frow, P., 2008. Managing the co-creation of value. Journal of the academy of marketing science, 36(1), pp.83-96.

Porter, M. E., 1985. Competitive Advantage. New York: Free Press.

Prahalad, C.K. and Ramaswamy, V., 2004. Co-creation experiences: The next practice in value creation. Journal of interactive marketing, 18(3), pp.5-14.

Pryke, S., 2017. Managing networks in project-based organisations. Hoboken, NJ: John Wiley \& Sons.

Redström, J., 2006. Towards user design? On the shift from object to user as the subject of design. Design studies, 27(2), pp.123-139.

Serrador, P. and Pinto, J.K., 2015. Does Agile work?-A quantitative analysis of agile project success. International Journal of Project Management, 33(5), pp.1040-1051.

Shenhar, A.J., Dvir, D., 2007. Reinventing project management: the diamond approach to successful growth and innovation. Boston, USA: Harvard Business Review Press.

Shostack, G., 1984. Designing Services that Deliver. Harvard Business Review, 62 (1): pp.133-39.

Spohrer, J., Maglio, P.P., Bailey, J. and Gruhl, D., 2007. Steps toward a science of service systems. Journal Computer, 40(1), pp. 71-77.

Storbacka, K., Brodie, R.J., Böhmann, T., Maglio, P.P. and Nenonen, S., 2016. Actor engagement as a microfoundation for value co-creation. Journal of Business Research, 69(8), pp.3008-3017.

Smyth, H., Morris, P., 2007. An epistemological evaluation of research into projects and

their management: Methodological issues. International Journal of Project Management, 25(4), pp.423-436

Smyth, H. and Pryke, S., 2008. Collaborative relationships in construction. Blackwell Publishing.

Smyth, H., 2015. Market Management and Project Business Development. (1st ed.). Abingdon: Routledge

Smyth, H. J., Fellows, R., Liu, A.M. and Tijhuis, W., 2016. Business development and marketing in construction, Construction Management and Economics, 34, pp. 205-217. 
Smyth, H., Lecoeuvre, L., Vasken, P., 2017. Co-creation of value and the project context: towards application on the case of Hinkley Point C Nuclear Power Station, International Journal of Project Management, in press and available online from 2017, http://www.sciencedirect.com/science/journal/aip/02637863?sdc=1.

Teixeira, J, Patrício, L, Nunes, N J, Nóbrega, L, Fisk, R. P. and Constantine, L. 2012. Customer experience modeling: from customer experience to service design. Journal of Service Management, 23(3):362-376

The Guardian, 2017. Students win $£ 1.5 \mathrm{~m}$ pledge after five-month rent strike. 6 Jul 2017. https://www.theguardian.com/education/2017/jul/06/students-win-15m-pledge-from-ucl-after-five-month-rentstrike (Accessed 19 December, 2017).

Times Higher Education 2015, Likely to have breached consumer law' in academic sanctions threat against rent strikers. November 13, 2015. https://www.timeshighereducation.com/news/ucl-likely-havebreached-consumer-law-academic-sanctions-threat-against-rent-strikers (Accessed 19 December, 2017).

Van de Ven, A.H. and Poole, M.S., 2005. Alternative approaches for studying organizational change. Organization studies, 26(9), pp.1377-1404.

Vargo, S.L. and Lusch, R.F., 2004. Evolving to a new dominant logic for marketing. Journal of marketing, 68(1), pp.1-17.

Vargo, S. L., Lusch, R. F., 2016. Institutions and axioms, an extension and update of service-dominant logic. Journal of the Academy of Marketing Science, 44(1), pp. 5-23.

Wetter-Edman, K., Sangiorgi, D., Edvardsson, B., Holmlid, S., Grönroos, C., \& Mattelmäki, T. (2014). Design for value co-creation: Exploring synergies between design for service and service logic. Service Science, 6(2), 106-121.

Wikström, K., Artto, K., Kujala, J., Söderlund, J., 2010. Business models in project business. International Journal of Project Management, 28(8), pp.832-841.

Williams, T. and Samset, K., 2010. Issues in front- end decision making on projects. Project Management Journal, 41(2), pp.38-49.

Winter, M., Smith, C., Morris, P. and Cicmil, S., 2006. Directions for future research in project management: The main findings of a UK government-funded research network. International journal of project management, 24(8), pp.638-649.

Wright, M. and Russell, D., 2012. Some philosophical problems for service-dominant logic in marketing. Australasian Marketing Journal (AMJ), 20(3), pp.218-223.

Woodall, T. (2003). Conceptualising 'value for the customer': an attributional, structural and dispositional analysis. Academy of marketing science review, 12(1), 1-42.

Wuisman, J.J., 2005. The logic of scientific discovery in critical realist social scientific research. Journal of Critical Realism, 4(2), pp.366-394.

Wynn Jr, D. and Williams, C.K., 2012. Principles for conducting critical realist case study research in information systems. MIS quarterly, pp.787-810.

Yin, R.K., 2017. Case study research and applications: Design and methods. London: Sage publications.

Zeithaml, V. A., Parasuraman, A., \& Berry, L. L. (1985). Problems and strategies in services marketing. The Journal of Marketing, 33-46.

Zerjav, V., Davies, A., Edkins, A. and Jones, P., 2015. Building Progressive Confidence: the Transition from Project to Operational Opening in the Case of a Major New International Airport Terminal. UCL STEaPP. 
Zerjav, V., Edkins, A. and Davies, A., 2018. Project capabilities for operational outcomes in interorganisational settings: The case of London Heathrow Terminal 2. International Journal of Project Management, 36(3), pp.444-459.

Zomerdijk, L. and Voss C., 2009. Service design for experience-centric services, Journal of Service Research, 13(1), pp.67-82.

Zwikael, O. and Smyrk, J., 2012. A general framework for gauging the performance of initiatives to enhance organizational value. British Journal of Management, 23(S1), pp.6-22. 